INTER NATIONAL MONETARY FUND
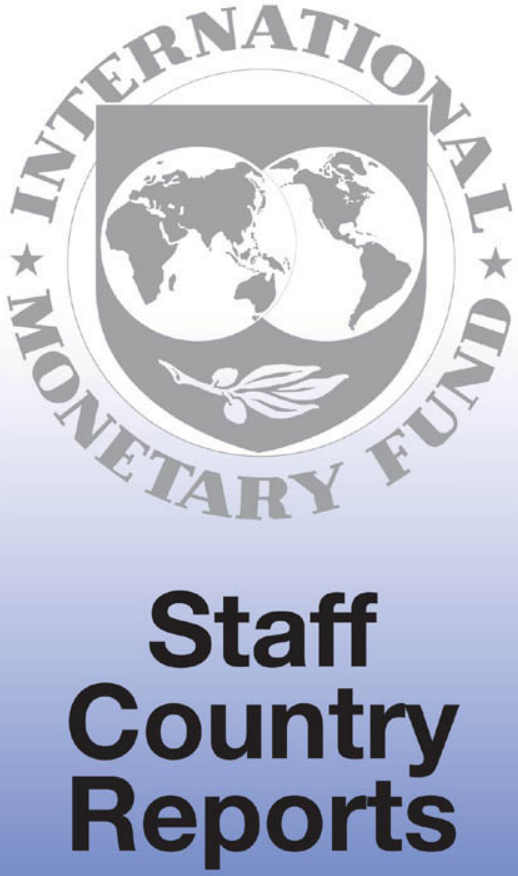


\section{Belize: Assessment of the Supervision and Regulation of the Financial Sector- Review of Financial Sector Regulation and Supervision}

This review of financial sector regulation and supervision in Belize in the context of the offshore financial center assessment program contains technical advice and recommendations given by the staff team of the International Monetary Fund in response to the authorities of Belize's request for technical assistance. It is based on the information available at the time of its completion. The views expressed in these documents are those of the staff team and do not necessarily reflect the views of the government of Belize or the Executive Board of the IMF.

The policy of publication of staff reports and other documents by the IMF allows for the deletion of market-sensitive information.

To assist the IMF in evaluating the publication policy, reader comments are invited and may be sent by e-mail to publicationpolicy@imf.org.

Copies of this report are available to the public from

International Monetary Fund • Publication Services

700 19th Street, N.W. • Washington, D.C. 20431

Telephone: (202) 6237430 • Telefax: (202) 6237201

E-mail: publications@imf.org • Internet: http://www.imf.org

Price: $\$ 15.00$ a copy

\section{International Monetary Fund Washington, D.C.}




\title{
ASSESSMENT OF THE SUPERVISION AND REGULATION OF THE FINANCIAL SECTOR
}

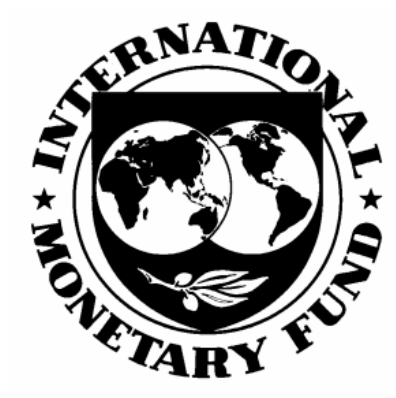

\section{Review of Financial Sector Regulation and Supervision}

\author{
BELIZE
}

\section{August 2004}


"The contents of this report constitute technical advice and recommendations given by the staff of the International Monetary Fund (IMF) to the authorities of a member country in response to their request for technical assistance. With the written authorization of the recipient country's authorities, this report (in whole or in part) or summaries thereof may be disclosed to IMF Executive Directors and their staff, and to technical assistance providers and donors outside the IMF. Disclosure of this report (in whole or in part) or summaries thereof to parties outside the IMF other than technical assistance providers and donors shall require the written authorization of the recipient country's authorities and the IMF's Monetary and Financial Systems Department." 


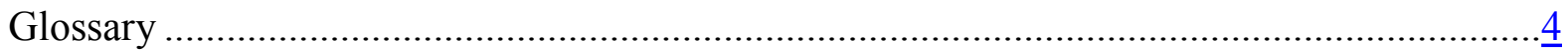

Preface

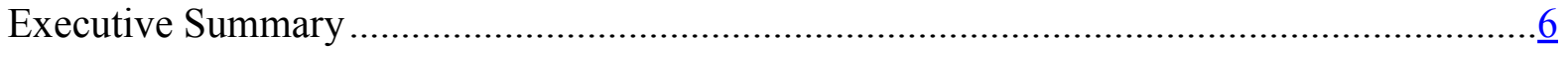

I. Introduction and Financial System Overview ………...................................................



B. Financial Institutions and Markets ...................................................................11

C. Anti-Money Laundering and Combating the Financing of

Terrorism (AML/CFT)Background .................................................................16

D. Regulatory Framework, Oversight, and Market Integrity Arrangements .................16

E. Strengths and Vulnerabilities in the Financial Regulatory and Supervisory Arrangements...............................................................................21

F. Cross-Border Cooperation and Information-Sharing …………………………....23

G. Key Observations and Recommendations ………………………………….......24

II. Observance of Financial System Standards and Codes: Reports on

Observance of Standards And Codes (ROSCs) ……………........................................25

A. Summary of the Basel Core Principles Assessment ……………………………...25

B. Summary of the IAIS Insurance Core Principles Assessment ...................................34

C. Summary of the Anti-Money Laundering and Combating the Finance of Terrorism (AML/CFT) Assessment ................................................................ 45

Tables

1. Financial Structure …………………..................................................................

2. Recommended Action Plan to Improve Compliance of the Basel Core Principles...........

3. Recommended Action Plan to Improve Observance of IAIS Insurance Core

Principles_-Domestic Insurance.....................................................................................

4. Recommended Action Plan to Improve Observance of IAIS Insurance Core

Principles - International Insurance .................................................................................42

5. Recommended Action Plan to Improve Compliance with the FATF

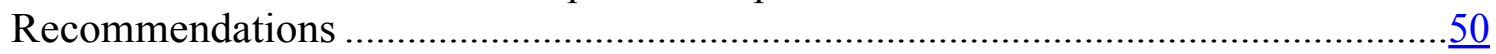

6. Other Recommended Actions .................................................................................

Boxes

1. Recent Legislative and Regulatory Initiatives ............................................................20 


\section{GLOSSARY}

\begin{tabular}{|c|c|}
\hline $\mathrm{BPD}$ & Belize Police Department \\
\hline BFIA & Banks and Financial Institutions Act \\
\hline CAIR & Caribbean Association of Insurance Regulators \\
\hline CALP & Caribbean Anti Money Laundering Program \\
\hline CBA & Central Bank Act \\
\hline $\mathrm{CBB}$ & Central Bank of Belize \\
\hline CED & Customs and Excise Department \\
\hline CFATF & Caribbean Financial Action Task Force \\
\hline CFZ & Commercial free zone \\
\hline CUA & Credit Unions Act \\
\hline DPP & Director of Public Prosecutions \\
\hline ECR & Exchange Control Regulations \\
\hline FI & Financial institution \\
\hline FIUA & Financial Intelligence Unit Act \\
\hline IA & Insurance Act \\
\hline IBA & International Banking Act \\
\hline IBCs & International business corporations \\
\hline IFS & International Financial Services \\
\hline IFSC & International Financial Services Commission \\
\hline IFSCA & International Financial Services Commission Act \\
\hline IFSCR & Prevention of Money Laundering and Other Criminal Activities \\
\hline IFSPR & International Financial Services Prevention Regulations \\
\hline IJPA & Indictable Jurisdiction Procedure Act \\
\hline IIA & International Insurance Act \\
\hline $\mathrm{JICC}$ & Joint Intelligence Coordinating Center \\
\hline KYC & Know-your-customer \\
\hline MDA & Misuse of Drugs Act \\
\hline MFA & Mutual Funds Act \\
\hline MLPA & Money Laundering Prevention Act \\
\hline MLPR & Money Laundering Prevention Regulations \\
\hline MOU & Memorandum of Understanding \\
\hline NJHQ & National Joint Headquarters \\
\hline OBA & Offshore Banking Act \\
\hline OGIS & Offshore Group of Insurance Supervisors \\
\hline OSI & Office of the Supervisor of Insurance \\
\hline SJPA & Summary Jurisdiction Procedure Act \\
\hline SOI & Supervisor of Insurance \\
\hline STR & Suspicious transaction report \\
\hline
\end{tabular}




\section{Preface}

At the request of the Belize authorities an IMF mission conducted a Module 2 Offshore Financial Center Assessment of Belize during August 4-15, 2003. The mission assessed observance by Belize of:

(a) the Financial Action Task Force 40 Recommendations for Anti-Money Laundering plus 8 Special Recommendations on Combating the Financing of Terrorism, based on the Methodology for Assessing Compliance with AntiMoney Laundering and Combating the Financing of Terrorism Standards (AML/CFT) October 2002 version;

(b) the Basel Core Principles for Effective Banking Supervision (BCP); and

(c) the Insurance Core Principles of the International Association of Insurance Supervisors (IAIS).

This report updates an OFC assessment undertaken in September 2001 and extends that assessment to include a comprehensive AML/CFT assessment using the common methodology adopted by the Fund/Bank and the FATF in the fall of 2002. The analysis and recommendations in this report reflect the situation as of the time of the on-site visit in August 2003. Subsequent to the mission the authorities developed a broad work program, which is still on-going, to address most of the recommendations in this report.

The mission consisted of Mr. John Abbott (Mission Chief, MFD); Ms. Joy Smallwood (Consulting Counsel, LEG); and Messrs. Joseph Courtright (Consultant, Banking Supervision, MFD); Peter Kruschel (Consultant, Banking, MFD); Martin Roberts (Consultant, Insurance, MFD); Richard Walker (Consultant, AML/CFT Financial Sector, MFD); and Ms. Maria Tramuttola (Administrative Assistant, IMF/MFD). An independent AML/CFT expert, not under the supervision of the IMF. Mr. Russell Ursala of the Caribbean Financial Action Task Force, evaluated the law enforcement sections of the AML/CFT methodology.

Members of the mission met with Mr. Ralph Fonseca, Minister of Finance and Home Affairs; Mr. Jorge Auil, Governor, Central Bank; Mr. Sidney Campbell, Deputy Governor of the Central Bank and Chairman of the International Financial Services Commission; Mr. Keith Arnold, Director of the Financial Intelligence Unit; Mr. Gian Gandhi, Director General, International Financial Services Commission and Legal Counsel, Finance and Home Affairs Ministry; Ms. Neri Matus, Financial Supervision Department, CBB; Ms. Alma Gomez, Acting Supervisor of Insurance; and Mr. Kirk Anderson, Director of Public Prosecutions, as well as a number of other financial and law enforcement officials. In addition, the mission had extensive discussions with representatives of the financial sector, including financial service providers. The members of the mission wish to express their gratitude to the Belizean authorities and the staff of all the institutions for their hospitality, cooperation, and openness in sharing insights and information. 


\section{EXECUTIVE SUMMARY}

The financial sector of Belize, both domestic and offshore, is small. At the end of 2002 assets of the domestic banking system totaled approximately US\$628 million and the international banks held additional assets of US\$148 million. There were five domestic banks and seven international banks. ${ }^{1}$ Domestic insurance assets totaled approximately US\$45 million at the end of 2001. Since the 1990s, official policy has fostered development of offshore financial activities. To date, formation of international business corporations (IBCs) and trusts have been the main lines of such international business. Over a span of thirteen years, a cumulative total of about 30,000 IBCs have been registered. After strike offs and dissolutions, 18,000 remain active. International insurance and mutual funds are authorized activities but it is only this year that the first licenses for these functions have been granted. Tax exemption, low registration costs, and a flexible trust law that facilitates asset protection trusts are among the advantages Belize offers as an offshore financial center.

A variety of actions have been taken in the last three years, particularly after the events of September 11, 2001, to strengthen financial supervision and improve the AML/CFT regime. These include the creation of an FIU (Financial Intelligence Unit) in late-2002 with broad powers to investigate and prosecute financial crime and to serve as the central coordinator for domestic and cross-border efforts against financial crime. Legislation has also been passed to implement UN conventions with respect to terrorist financing. The International Banking Act was amended to better align regulatory requirements with those of domestic banks and with international standards. Further legislative initiatives are underway to update the provisions for supervision of domestic banking and domestic insurance.

The assessment found that banking supervision complies with or is largely compliant with most of the Basel Core Principles. Under current arrangements the Minister retains a good deal of discretionary authority with respect to banking supervision, but this situation is likely to be modified if a draft bill, now under discussion, becomes law. Retention of qualified staff is a continuous problem with the result that the intensity of banking supervision varies. With the addition of more international banks and other mergers and expansions, the corporate structures of banks are becoming more complex, requiring greater attention of cross-border and consolidated supervision issues.

Legislation for the supervision of domestic insurance is outdated and is being revised. Because of staff constraints, the insurance supervisor has limited ability to put forward a comprehensive program of on-site and off-site supervision. Still, close monitoring and active dialogue seem to be providing an adequate level of oversight even though the processes fall short of many of the international standards for insurance supervision.

\footnotetext{
${ }^{1}$ In Belize the classification of banks and insurance companies as either "domestic" or "international" is based on the type of business they are authorized to do, not the residency of their owners. Domestic banks are authorized to deal with domestic residents, and in local currency. International banks are authorized to deal with non-residents, exclusively in foreign currency.
} 
The authorities have been careful to develop basic licensing requirements before allowing international insurance to proceed. A few licenses have recently been granted but business is only beginning. Arrangements for the on-going, prudential supervision of these activities have, until now, been deferred. The mission offered a number of suggestions for upgrading supervision of international insurance to a level that would satisfy international standards.

With the establishment of the FIU, the AML/CFT regime has been considerably strengthened. The FIU Act makes the director of the FIU the supervisor authority for implementing the Money Laundering Prevention Act and puts the FIU at the center of government efforts to deal with financial crime. Because of the large number of agencies involved, close coordination will be required to make the new FIU regime fully effective. Not surprisingly some teething problems have been encountered in the early months of operation. While many of the elements of a robust AML/CFT regime are now in place, the mission made a number of specific recommendations with respect to law, regulation, and operations that would further strengthen the overall regime.

AML/CFT awareness is generally high both in the government and in the private sector. While identified cases of money laundering within Belize have been few, several elements of the Belize financial structure pose special vulnerabilities to money laundering that will require continuing vigilance and, perhaps, some tightening up of practices. Issues arise particularly with respect to the heavy reliance of the trust and company service provider sector on overseas introductions, where verification of beneficial owners is particularly difficult. Belize trust structures are attractive to parties wishing to put assets out of reach of legitimate claimants. Also, Belize has commercial free zones where cash transactions are prominent and controls are difficult to enforce, and also casa de cambio exchange operations, where monitoring of cash transactions is also difficult. The authorities are aware of these vulnerabilities and have taken specific steps to mitigate some risks.

The supervisory regime in Belize consists of a variety of agencies having responsibility for sub sectors. As a result, prudential supervision is uneven, with important institutions little supervised. As well, there are gaps in the regime for monitoring compliance with AML/CFT requirements. None of the supervisory agencies has the critical mass necessary to comply fully with international standards. The financial system is continuing to evolve and will become more complex as new services and products and financial structures are introduced. A common theme of the separate assessments is that additional resources and skills are needed if Belize is to be able to satisfy international standards. As the government moves to meet these standards, the mission believes it would be most cost effective to simultaneously address the issue of various supervisors and move toward a more streamlined system. A single financial supervisor is one option, but the mission has also included suggestions for intermediate steps on the path to a more streamlined and cost effective system of financial regulation. The mission believes it would be useful for the authorities to undertake a feasibility study to consider merger of the separate domestic and international insurance functions into a single body. Merger could address resources problems identified in this assessment but a feasibility study would also afford an opportunity to review and improve issues relating to independence and as appropriate, consistency of supervisory standards, guidelines, processes and decisions. 


\section{KEY RECOMMENDATIONS}

\begin{tabular}{|c|c|}
\hline Issue & Recommendation \\
\hline \multicolumn{2}{|l|}{ Banking } \\
\hline $\begin{array}{l}\text { Operational } \\
\text { independence of the } \\
\text { supervisor }\end{array}$ & $\begin{array}{l}\text { The authorities should consider amending the legislation to remove the Minister of Finance's } \\
\text { power to approve or withdraw licenses, to approve significant enforcement actions and to } \\
\text { approve selection of most CBB employees. These measures would remove the potential for } \\
\text { intrusion by the Minister on the operational independence of the CBB. (Subsequently, } \\
\text { amendments to the BFIA and IBA were proposed for consideration.) }\end{array}$ \\
\hline $\begin{array}{l}\text { On-site and off-site } \\
\text { banking supervision }\end{array}$ & $\begin{array}{l}\text { The CBB should consider an increase in the number and breadth of expertise of their banking } \\
\text { supervision staff, introduction of a comprehensive examination manual, which, among other } \\
\text { things, would include the adoption of a more formalized system of working papers for onsite } \\
\text { examinations. (Training and technical assistance is being undertaken to address these } \\
\text { recommendations.) }\end{array}$ \\
\hline $\begin{array}{l}\text { Consolidated } \\
\text { supervision }\end{array}$ & $\begin{array}{l}\text { In its capacity as both a home and a host supervision and drawing on the tools of consolidated } \\
\text { supervision, the CBB should develop procedures to ensure that the common ownership } \\
\text { structure of some international banks does not undermine effective supervision and that } \\
\text { consolidated supervision is, in general, effective. (Subsequently, measures were taken to } \\
\text { consolidate one bank as a subsidiary of a foreign bank, to enter into an MOU with the home } \\
\text { country supervisor of another commonly-owed bank, and to formalize CBB policy that } \\
\text { international banks must have a bank parent.) }\end{array}$ \\
\hline \multicolumn{2}{|r|}{ 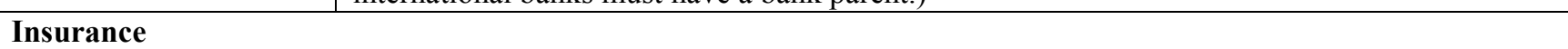 } \\
\hline $\begin{array}{l}\text { Developing on-going } \\
\text { supervision for } \\
\text { international insurance }\end{array}$ & $\begin{array}{l}\text { The International Supervisor of Insurance (ISO) should, as a matter of urgency, acquire the } \\
\text { resources necessary to understand and assess potentially complex insurance operations, the } \\
\text { viability of their business plans, and the adequacy of their resources, having regard for the } \\
\text { nature of business written. He should also develop the capacity to carry out on-site inspections. }\end{array}$ \\
\hline $\begin{array}{l}\text { Broadening guidance } \\
\text { given to domestic } \\
\text { insurance }\end{array}$ & $\begin{array}{l}\text { Guidance notes should be issued to the domestic insurance industry dealing with corporate } \\
\text { governance and internal controls, particularly with respect to standards for monitoring } \\
\text { underwriting risks, claims, compliance with the law, fair treatment of customers and AML } \\
\text { requirements. }\end{array}$ \\
\hline $\begin{array}{l}\text { Developing on-site } \\
\text { supervision }\end{array}$ & $\begin{array}{l}\text { The Supervisor of Insurance should develop a fully structured on on-site program, including a } \\
\text { comprehensive inspection manual which covers all major areas of insurance practices. }\end{array}$ \\
\hline Resources & $\begin{array}{l}\text { At least two experienced staff should be hired to allow more intensive supervision, including } \\
\text { through on-site inspections and through more system analysis and evaluation of companies } \\
\text { activities and financial reports. Staff training should be expanded, particularly in the areas of } \\
\text { reinsurance and insurance risk analysis. }\end{array}$ \\
\hline \multicolumn{2}{|l|}{ AML/CFT } \\
\hline $\begin{array}{l}\text { Strengthening } \\
\text { AML/CFT legal } \\
\text { framework }\end{array}$ & $\begin{array}{l}\text { Substantial AML/CFT legislation is in place but specific details should be filled in including: } \\
\text { signing and ratifying the Palermo convention, introducing authority for a broader range of } \\
\text { sanctions, broadening asset freezing and forfeiture authority, providing explicitly for an } \\
\text { analytical function for the FIU, and considering adoption of a proceeds of crime law, a mutual } \\
\text { assistance law, and adopting an "all serious crimes" approach to predicate offences. }\end{array}$ \\
\hline Skills development & $\begin{array}{l}\text { More and continuous training should be provided to supervisory, administrative, investigative, } \\
\text { prosecutorial and judicial authority for enforcing the relatively new ML/FT laws of Belize. The } \\
\text { analytic capabilities of the FIU should be enhanced. }\end{array}$ \\
\hline Improving coordination & $\begin{array}{l}\text { The FIU should step up its coordinating efforts in order to establish clearer processes and } \\
\text { policies between the different entities (e.g., between the Central Bank and the FIU, between the } \\
\text { FIU and the DPP's office, between the FIU and BPD) involved in enforcing ML and FT laws } \\
\text { and regulation. }\end{array}$ \\
\hline $\begin{array}{l}\text { Improving the } \\
\text { framework for use of a } \\
\text { eligible introducers }\end{array}$ & $\begin{array}{l}\text { Consideration should be given to amending the framework for introduced business, to remove } \\
\text { the option in which verification documents can be retained by an eligible introducer. }\end{array}$ \\
\hline $\begin{array}{l}\text { Facilitating exchanges } \\
\text { of information }\end{array}$ & $\begin{array}{l}\text { Gateways for information flow should be extended so that information on banking, insurance, } \\
\text { mutual funds, managers, administrators and any other information can be transmitted to other } \\
\text { regulatory bodies pursuant to international standards for the investigation and prosecution of }\end{array}$ \\
\hline
\end{tabular}




\section{KEY RECOMMENDATIONS}

\begin{tabular}{|l|l|}
\hline \multicolumn{1}{|c|}{ Issue } & \multicolumn{1}{c|}{ Recommendation } \\
\hline & economic crime. \\
\hline $\begin{array}{l}\text { Ensuring } \\
\text { comprehensive } \\
\text { compliance monitoring }\end{array}$ & $\begin{array}{l}\text { The capacity should be developed to monitor and ensure compliance with the preventive } \\
\text { measures required of credit unions, casas de cambio, and for entities and service providers } \\
\text { licensed by the IFSC, regardless of whether this activity is carried out by the FIU or by the } \\
\text { individual licensing/professional body. To comply with the June 2003 revised FATF Forty } \\
\text { Recommendations, this capacity should also extend to the preventive measures required of } \\
\text { lawyers and accountants. }\end{array}$ \\
\hline Guidance notes & $\begin{array}{l}\text { As soon as possible, the FIU, in conjunction with the various supervisory agencies, should issue } \\
\text { updated AML/CFT guidance notes appropriate for the entire financial system and, as necessary, } \\
\text { supplemented by guidance tailored to individual sectors of the financial community. }\end{array}$ \\
\hline
\end{tabular}

Subsequent to this assessment, numerous steps were taken to strengthen supervision of banking and domestic insurances, including enactment of proposed insurance legislation. While IMF experts have not had an opportunity to review these measures in detail, they appear to go a long way toward addressing a number of recommendations in this report. Key actions include: (i) enactment of a new Insurance Act for domestic insurance; (ii) adoption of various new banking and insurance regulations; and (iii) additional technical assistance and training to upgrade supervisors' capacity to conduct off-site monitoring and on-site examination of banks and insurance companies. 


\section{INTRODUCTION AND FINANCIAL SYSTEM OVERVIEW}

1. Volume I of the report briefly describes the financial system and regulatory and supervisory arrangements for the financial sector in Belize and provides reports on the observance of standards and codes (ROSCs) based on the detailed assessments in Volume II. Volume II provides the detailed assessments carried out on the basis of the Basel Core Principles for Effective Banking Supervision, the IAIS Insurance Core Principles, and the Anti-Money Laundering and Combating the Finance of Terrorism (AML/CFT) Methodology for assessing compliance with the Financial Action Task Force (FATF) 40+8 Recommendations.

2. This section provides an overview of the financial institutions and markets in Belize, and the legal and institutional framework for the regulation and supervision of the financial system.

\section{A. Background}

3. Belize is an English-speaking democratic nation situated on the northeastern tip of Central America. With three hundred miles of Caribbean coastline, it is a crossroad between the Caribbean and Latin America. A member of the British Commonwealth, Belize gained independence in 1981 and its political, legal, economic and educational systems are based on the British model. As a parliamentary democracy, Belize retains Queen Elizabeth II, represented by Governor General as its Head of State. The Government is headed by a Prime Minister. The National Assembly is a bicameral legislature. The Senate is a twelve-member body, six of whom are appointed by the Ruling party, three by the Opposition, one by the Council of Churches, one by the Business Community, and one by the Unions. The House of Representatives consists of 29 elected Members. Elections were held in March 5, 2003, with the current government gaining 22 seats in the National Assembly.

4. Belize issues its own currency, the Belize dollar (BZ\$), which since 1976 has been fixed by law at an exchange rate of 2:1 against the U.S. dollar. Exchange control legislation is in force. Belize operates a complex fiscal regime, with a variety of exemptions and reduced rates designed to create incentives for targeted activities, particularly exports and inward investment. The business tax ranges from 1.25-1.75 percent of turnover. Stamp duty of 15 percent is applied on transfer of real property and various stamp duties and turnover taxes are applied on financial transactions. The standard sales tax rate is 8.0 percent and a payroll tax of up to 25 percent for BZ\$20,000 and above. The standard social security contribution is 8.0 percent.

5. The main areas of economic activity are agriculture (particularly sugar, citrus, and fish farming), and tourism. Financial services account for approximately 6 percent of GDP. GDP in 2002 was approximately US $\$ 850$ million, and, with a population approximately 264,000, per capita GDP was estimated to be US\$3,250. 


\section{B. Financial Institutions and Markets}

6. The Belize financial sector is not large by international standards, nor is it large relative to domestic GDP. As of the end of 2002, assets of the banking sector amounted to approximately US\$776 million, of which 81 percent was attributable to domestic banks and 19 percent to international banks. Insurance companies' total assets amounted to US\$51 million at the end of 2002. A range of financial services are offered in Belize and are provided by a variety of institutions, including banks, insurance companies, building societies, credit unions, providers of international business services, and the governmentowned Development Finance Corporation.

\section{Banking}

7. The banking sector in Belize consists of four domestic-licensed commercial banks. Three of these are locally incorporated and one is a branch of a Barbados bank. Three of the banks have significant foreign ownership. In addition, there are seven international banks (six with foreign ownership, one with substantial common ownership with a local commercial bank); and three quasi-government banks. In addition, there are building societies and credit unions engaged in deposit taking and lending activities similar to banks. One of the domestic commercial banks and five of the offshore banks have been licensed since 2000.

8. Belize Bank Ltd. is responsible for nearly half of the assets of the domestic banks. One local bank (Alliance) was licensed and began operations in 2001. The branch of Barclays restructured as a branch of a new First Caribbean International Bank (Barbados), Ltd. (a merger of Barclays and CIBC) which itself is part of a bank holding company, CIBC West Indies Holdings. In 2003, the branch of the Bank of Nova Scotia was converted into a wholly owned local subsidiary of Bank of Nova Scotia International (Bahamas), Ltd. The four banks operating in the local market conduct virtually all their business in Belize and in local currency and, therefore, are heavily dependent on the economic success of the country. Assets tend to be well diversified across economic sectors and to be well secured by realizable collateral but should there be a significant and sustained downturn in the economy; the banks could face difficult problems. Potential support from foreign parents has been reduced as a result of recent mergers and restructurings (Table 1). 
Table 1. Financial Structure

\begin{tabular}{|c|c|c|c|c|c|}
\hline & 1998 & 1999 & 2000 & 2001 & 2002 \\
\hline & \multicolumn{5}{|c|}{ (In Belize dollars, unless otherwise specified) } \\
\hline \multicolumn{6}{|l|}{ Sector } \\
\hline \multicolumn{6}{|l|}{ Banks } \\
\hline \multicolumn{6}{|l|}{ Domestic } \\
\hline Total assets & 820.0 & 909.7 & $1,004.2$ & $1,181.3$ & $1,257.2$ \\
\hline Total loans & 591.2 & 653.7 & 687.1 & 758.3 & 940.4 \\
\hline Total deposits & 702.0 & 785.8 & 866.0 & $1,005.5$ & $1,060.3$ \\
\hline Primary capital/assets (in percent) & 7.9 & 8.5 & 10.5 & 10.4 & 12.8 \\
\hline Adversely classified loans/gross loans (in percent) & 5.5 & 3.4 & 6.2 & 4.5 & 3.4 \\
\hline \multirow[t]{2}{*}{ Return on equity (in percent) } & 30.5 & 36.3 & 46.6 & 41.0 & 36.8 \\
\hline & \multicolumn{5}{|c|}{ (In U.S. dollars, unless otherwise specified) } \\
\hline \multicolumn{6}{|l|}{ Foreign } \\
\hline Total assets & & & & 101.6 & 148.0 \\
\hline Total loans & & & & 64.5 & 75,7 \\
\hline Balance with correspondent banks & & & & 25.5 & 43.4 \\
\hline Total deposits & & & & 93.9 & 132.1 \\
\hline Primary capital/assets (in percent ) & & & & 4.6 & 6.5 \\
\hline Adversely classified loans/gross loans (in percent) & & & & 0.0 & 0.84 \\
\hline Return on equity (in percent) & & & & 30.1 & 45.1 \\
\hline
\end{tabular}

(In Belize dollars, unless otherwise specified)

Insurance

\section{Gross premiums}

Total

General

Long term

Reinsurance premiums

Total

General

Long term

Gross claims

Total

General

Long term

Total assets

Number, incorporated, by type

Total

Long term

General

Composite

Association of underwriters

Credit unions 1/

Total assets

Total loans

Total savings

Number members

Registered company service providers

Company formation agents

Trustees and trust service provider

Mutual fund

International insurance

Registered IBC, cumulative, 1990-Aug 2003

Registered IBC, active, Aug. 2003

$1 /$ As per year ending March 31

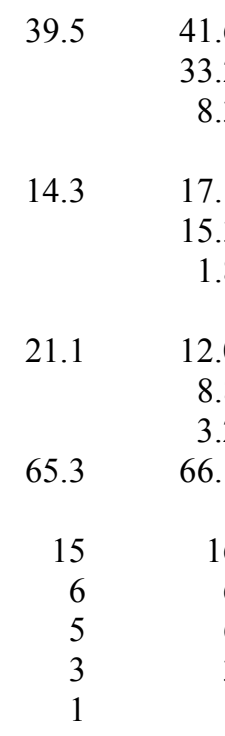

48.7

37.5

11.2

18.8

17.3

1.5

60.9

57.7

3.2

91.9

18

6

8

3

1

208.5

165.4

154.6

70,233

$\begin{array}{rr}60.9 & 80.1 \\ 46.5 & 59.9 \\ 14.4 & 20.3 \\ & \\ 24.1 & 27.9 \\ 21.3 & 25.6 \\ 2.8 & 2.3\end{array}$

53.4

24.9

$49.3 \quad 14.1$

$4.1 \quad 10.8$

$89.4 \quad 101.7$

$\begin{array}{rr}18 & 18 \\ 6 & 6 \\ 8 & 8 \\ 3 & 3 \\ 1 & 1\end{array}$

237.9

192.1

178.4

70,655 
9. International banks are restricted to doing business in foreign currency with nonresidents. Several of the smaller foreign owned international banks are affiliates/subsidiaries banks in neighboring countries (Costa Rica, Guatemala, and Honduras) and are primarily engaged in offering foreign currency deposits and foreign currency loan facilities to clients of the home country parent. As of August 2003 only two international banks had common ownership structures with overseas banking groups and subsequently one of these restructured as a subsidiary of the home country parent. For the other bank, the Central Bank is in the process of signing an MOU with the home country supervisor. Until recently, assets of international banks had consisted mainly of foreign securities and placements abroad. The International Banking Act was amended in 2002 to allow international banks also to lend in Belize in foreign currency to firms operating in Export Processing Zones (EPZ) and in Commercial Free Zones (CFZ). As a result, loans to such firms, supported by foreign currency export proceeds and secured by collateral realizable in Belize, have expanded rapidly. International banks fund themselves largely from client deposits and from foreign currency term deposits marketed in relatively small denominations to non-resident individuals seeking either security or above market yields.

\section{Insurance}

10. The domestic insurance market in Belize is small. Figures for 2002, show that gross premiums of the registered insurers were approximately BZ\$80 million (US\$40 million) and that total assets were about BZ\$102 million (US\$51 million). General insurance accounts for three quarters of this total, with property, motor, and accident and sickness being the principal lines of business. Motor insurance is compulsory in Belize. Long term insurance accounts for about one quarter of total insurance assets. Most of this is attributable to life insurance, although the annuity business has begun to grow in the last two years. In general, the market is heavily reliant on overseas reinsurance, particularly for windstorm and flood catastrophe cover.

11. Seventeen insurance companies and one underwriting association were registered under the Insurance Act to carry on insurance business in Belize, as of the end of 2002. Of this total, six were long-term insurers, eight were general insurers, and three were composite companies. One composite company is under judicial management.

12. International insurance, first authorized in 1999, has been slow to develop. During the first half of 2003 five firms were licensed to provide international insurance services but it is not clear that any are yet active, in part because suitable reinsurance arrangements have been difficult to establish.

\section{Non-Bank Offshore Sector}

13. Development of an offshore financial sector has been a policy objective of the Belize government since the early-1990s. In addition to international banking, which falls under the Central Bank, a variety of offshore investment vehicles are authorized, registered, or regulated by the International Financial Services Commission (IFSC). These include offshore 
insurance, trusts, mutual funds, protected cell companies, partnerships, and limited life companies. Legislation also provides for the formation and registration of international business companies (IBC). Offshore financial activities are generally exempt from Belize taxation.

14. Trusts and IBCs account for the bulk of the non-bank offshore business. As of mid2003 a cumulative total of 31 thousand IBCs had been registered since the Registry was launched in 1990. After strike-offs and dissolutions, approximately 18 thousand are still considered active. IBCs may only be owned by non-residents and are exempt from Belize taxation. No record is maintained as to the number of trusts or the value of assets in Belize trusts. No meaningful statistics are available on the business purposes of Belize IBCs or the geographic distribution of ownership. However, discussions with industry practitioners suggest a large proportion of IBCs are organized for asset holding purposes (both real and financial) with a roughly equal distribution between corporate and individually owned IBCs. The geographic pattern of ownership is widely disbursed among Western Hemisphere, European, and Asian owners. Practitioner comments suggest that Belize IBCs have become popular vehicles for structuring investments into China with this sector of the market expanding rapidly recently in line with the expansion of international investment into China. Creation of IBCs by central and eastern European persons also appears to be growing rapidly. Some IBCs involve ancillary banking business in Belize which requires a special license from IFSC.

15. Incorporation of IBCs in Belize is low cost and efficient. Practitioners state that official fees for Belize IBCs run considerably less than for IBCs formed in competitor centers such as BVI. (Belize requirements are patterned after those of BVI.) IBCs are required to have a registered agent in Belize and it is the registered agent who bears the responsibility for vetting IBCs and, in particular, is responsible for all due diligence related to establishing identity and maintaining information on beneficial ownership of IBCs. The information requirements of the Registrar are minimal and straightforward (name of owners of record, official registered agent, capital structure, types of shares, number of directors, business objectives, powers of owners and directors). Registration provides legal validity to the IBC and the registered agent serves as the custodian of documents of incorporation. The international business company registry, IBC Registry, is a privatized concession based on an agreement between the government and a private sector company, the Belize International Services Limited (BISL). The Registry is computerized and, among practitioners, has a reputation for clerical efficiency.

16. The Trust Act allows considerable flexibility in asset management and is particularly useful for asset protection and estate planning purposes. The Law of Property Act, the Bankruptcy Act, and certain provisions of the Reciprocal Enforcement of Judgments Act, have been disapplied, thus providing "protection" from valid claims even if the transfer into the trust would have been illegal in the other jurisdiction or in Belize. Oral trusts are permitted. Belize trusts provide a high degree of privacy. Identification of beneficial ownership may be required in cases of criminal investigations. Trusts are not registered, although the government has expressed an interest in establishing a trust registry. 
17. Company formation agents and persons engaged in the management or provision of offshore trusts or trustee services are required to be licensed by the IFSC. As of mid-August 2003, 42 firms or individuals had been licensed as registered agents for IBCs, 21 as providers for trustee services, two as insurance companies, two as licensed insurance managers and one as a representative insurance agent. In addition to providing a range of legal, accounting, custodial, administrative, and management services, offshore practitioners who act as registered agents are required by regulation to be the custodians of bearer shares issued by IBCs, to establish and maintain the identity of beneficial owners, to maintain a registry of current directors, and to maintain a registry of charges for their trusts or IBCs. Trust and company service providers in Belize have a reputation for providing efficient service in a cost effective manner, although practitioners state that their costs are rising as a result off more demanding AML/CFT regulations.

\section{Other}

18. Other elements of the private sector financial system include credit unions, building societies, and a domestic mutual fund. As of March 2002, there were 15 registered credit unions with total assets of BZ\$237.9 million. The largest credit union, Holy Redeemer, accounted for 75 percent of this total. A new Credit Union Act in 2002 introduced more detailed commercial and regulatory standards for credit unions. Two building societies have been authorized, one of which is dormant. No public information is available on the operations of the one active building society. The Development Finance Corporation (DFC) is a relatively large public bank which provides a wide range of credit facilities to support development projects such as housing, housing mortgages, tourism facilities, transportation, infrastructure and education. Funding for DFC is provided by credit facilities from international development agencies, the government, commercial borrowing, private placements, and securitizations. Although allowed to, DFC does not accept deposits from the public. After a period of rapid expansion after 1998, the DFC is now undergoing consolidation.

19. In the past year, in an effort to regularize parallel currency transactions, Casa de Cambios have been authorized, subject to licensing by the Central Bank. A total of 14 cambios have been licensed. Cambios are limited to exchange transactions of up to US\$2,500 (up to US\$10,000 with Central Bank authorization). They are required to have premises, to maintain transactions records, and to file reports with the Central Bank. Tourism, worker remittances, pensions and gifts appear to be the primary sources of foreign exchange for the cambios. Commercial firms appear to be the major purchasers of foreign exchange from the cambios. Central Bank statistics indicate that turnover is on the order of US\$2.0 million per month. Reportedly, the parallel market continues to be active so it is uncertain what percentage of transactions may have been diverted from other formal and informal markets to the new cambio system. 


\section{Anti-Money Laundering and Combating the Financing of Terrorism (AML/CFT) Background}

20. The legal framework for AML/CFT includes the Money Laundering (Prevention) Act, 2000; the Money Laundering (Prevention) (Amendment), Act No. 5, 2002; the Financial Intelligence Unit Act, 2002; and the Money Laundering Prevention Guidance Notes, as well as elements of other legislation. In addition, Belize has ratified the Vienna Convention and signed the UN International Convention for the Suppression of the Financing of Terrorism.

21. Based on various reports and discussions with the authorities Belize faces a variety of vulnerabilities to money laundering, particularly outside the formal financial system. Nonetheless, both the authorities and private sector contacts believe money laundering activity within Belize is limited. Belize is a transshipment point for cocaine and marijuana. However, the authorities believe there is relatively little financial activity within Belize associated with this drug movement. A commercial free zone on the Mexican border is understood to generate a significant volume of cash transactions, particularly in Mexican pesos and U.S. dollars. In an effort to promote better compliance with various regulatory requirements, over the past year the Free Zone Management Agency has introduced a compliance agency. Among its activities, the agency is promoting better adherence to requirements that zone firms use Belize banking channels for their financial transactions. Additional CFZs are planned at other border points. Notwithstanding official controls, both bankers and AML officials expressed concern that both free zones and the more recently authorized cambios have opened avenues for illicit cash to enter the formal financial system with limited ability to identify the true source of funds. Unsupervised money transmitters are another potential vulnerability to the AML/CFT regime, although their operations are understood to be small. Other potential points of vulnerability outside the formal financial system include two private casinos and internet gambling in EPZs.

\section{Regulatory Framework, Oversight, and Market Integrity Arrangements}

\section{Structure of financial supervision}

22. Financial supervision is being conducted by several supervisory agencies.

Supervision of banks, both domestic and international, is the responsibility of the central bank. Separate legislation governs domestic and international banks although, in practice, both types of banks are subject to similar supervision. The Supervisor of Insurance, an official of the ministry of finance, is responsible for Supervision of domestic insurance companies under the Insurance Act and the Motor Vehicle (Third Party Risks) Act. International insurance companies, subject to a separate International Insurance Act, are supervised by the Supervisor of International Insurance who operates under the aegis of the International Financial Services Commission (IFSC). The Director General of the IFSC is currently the Supervisor of International Insurance. He is also an official of the Ministry of Finance and Home Affairs. Credit unions and building societies are registered by the Registrar of Credit Unions and the attorney general, respectively, but are not subject to systematic prudential regulation. The Central Bank has authority to require reports from 
building societies, and to examine these entities. Beginning in September 2002, the Central Bank for the first time invoked this authority to examine the one active building society. The Development Finance Corporation (DFC) has not been subject to third-party prudential regulation. On December 31, 2003 the CBB informed DFC that effective January 2004 CBB will begin to supervise them. An on-site examination is to be conducted during 2004.

23. Banking supervision follows a traditional CAMEL approach, with a combination of off-site monitoring and on-site examination. The banking supervision department of the Central Bank has eleven professionals. As a result of staff turnover, five of these staff members have been added within the past year.

24. Regulation of the insurance industry is divided between two supervisors, one for domestic insurance and the other for international insurance, each governed by separate insurance acts. The Acting Supervisor of Insurance, who is responsible for domestic activities, reports to the Office of the Superintendent of Insurance, which is under the Ministry of Finance and Home Affairs. Domestic insurance business is governed by the Insurance Act, which has been in effect since 1976. As noted, the Director General of the IFSC currently functions as the supervisor of international insurance.

25. The insurance supervisory process in Belize focuses on traditional off-site supervision. The process revolves around the licensing and regular monitoring of the insurance companies. This monitoring primarily involves the inspection of audited annual financial returns and regular contact with the management of insurance companies to discuss material changes in business and general market matters.

26. Supervision of non-bank offshore activities - international insurance, international mutual funds, IBCs, and trust and company service providers - is the responsibility of the IFSC. This Commission is a mixed private sector/public sector body. Of eight directors, five are from the private sector and three are from the public sector. The Chairman is (currently) the Deputy Governor of the Central Bank and the Director General is the chief counsel of the Ministry of Finance and Home Affairs. Licensing of international financial service providers is a primary activity of the IFSC. The Director General of the IFSC is the appointed Supervisor of International Insurance, the Registrar of Mutual Funds, and the Registrar of IBCs. Each of these positions, which are all ministerial appointments, provide for the incumbent to administer the laws and regulations relevant to each activity. Decision making authority, however, resides with the full Commission. In a recent speech, the Director General characterized the regulatory regime administered by the IFSC as one of "selfregulation." Administration of the IFSC and its related regulatory responsibilities is a part time activity for the Director General, assisted by one professional and one clerical staff of the Ministry of Finance and Home Affairs, who also work part-time on IFSC regulatory matters. IFSC supervision emphasizes promulgation of regulation and a mandatory code of conduct, as well as licensing processes. Compliance checking, reporting and on-going supervision are little emphasized. 
27. A Financial Intelligence Unit (FIU) was established in December 2002 with broad responsibility to investigate and prosecute financial crimes, function as the Supervisory Authority for the Money Laundering Prevention Act, ensure coordination among government departments, regulatory agencies, and private parties in the prevention and suppression of financial crimes, and to receive suspicious transactions reports, issue guidelines, and deal with legal assistance and exchange of information matters. The FIU is also required to promote awareness of AML/CFT issues and responsibilities among the public. The FIU has four professional staff members including the Director, a financial examiner, and two police officers. While a very new agency, the FIU has quickly taken on a central role in financial investigations and in the formulation and execution of government-wide policies with respect to AML/CFT matters. Working relationships with other regulatory and law enforcement agencies are still evolving as all parties gain familiarity with the new arrangements. (Sections below elaborate on the activities of the FIU.)

\section{Previous Assessments and Recent Developments}

28. Since 2000, the regime in Belize for financial supervision and for AML/CFT has been reviewed by various international bodies. A mutual evaluation in 2000 by the Caribbean Financial Action Task Force (CFATF) concluded that "Belize has in place the general legislative requirements advanced by the Financial Action Task Force (FATF) and CFATF to effectively combat money laundering." The report went on to observe that "the anti-money laundering regime is, however, still in its infancy as highlighted by the low level of suspicious transaction reports filed and the lack of any arrests or criminal charges to date."

29. In May 2000, the Financial Stability Forum (FSF) categorized Belize as a Group III jurisdiction based on "their perceived quality of supervision and perceived degree of cooperation." Group III jurisdictions are "generally perceived as having legal infrastructures and supervisory practices and/or a level of resources devoted to supervision and cooperation that are largely of a lower quality."

30. The September 2001 OFC assessment by the IMF identified numerous weaknesses in financial supervision practices, but observed that the domestic sector was generally better regulated than the offshore sector. A critical lack of qualified and experienced staff in all supervisory agencies was identified as a major factor contributing to supervisory weaknesses. The number of supervisory agencies and division of responsibilities was also considered an important weakness in the overall supervisory regime.

31. The September 2001 OFC mission made numerous recommendations, including:

- $\quad$ reinforcing efforts to implement the AML/CFT regime to include creation of an FIU, increased training and awareness activities for both the public and private sectors, and more active involvement by the police;

- $\quad$ increasing the autonomy and authority of supervisors by reducing the involvement of both ministers and the private sector in operational decisions, and separating the promotional and supervisory functions of the IFSC; 
- $\quad$ upgrading the staffing, training, and expertise of supervisors;

- $\quad$ unifying regulation of domestic and offshore insurance;

- $\quad$ strengthening and making the enforcement powers of supervisors more uniform;

- $\quad$ subjecting building societies and larger credit unions to the same regulatory and supervisory regimes as banks;

- $\quad$ developing procedures and expertise for prudential oversight of the DFC with a view to eventual supervision by the central bank; and

- $\quad$ strengthening regulation and ongoing supervision of companies, trusts and company, and trust service providers, with a particular emphasis on arrangements that allow the verification of beneficial ownership and that deter misuse of investment vehicles for illicit purposes.

32. Subsequent to these reviews, but particularly after the events of September 11, 2001, Belize adopted a number of legislative, regulatory and policy initiatives to respond to various international recommendations and to update the framework for its financial system. Box 1 summarizes the major initiatives.

33. In addition, as noted above, following the conclusion of the IMF assessment mission in August 2003 a number of further steps were taken to strengthen the regulatory framework, particularly with respect to banking and domestic insurance, including enactment of proposed insurance legislation. While IMF experts have not had an opportunity to review these measures in details, they appear to go a long way toward addressing a number of recommendations in this report. Key actions include: (i) enactment of a new Insurance Act for domestic insurance; (ii) adoption of various new banking and insurance regulations; and (iii) additional technical assistance and training to upgrade supervisors' capacity to conduct off-site monitoring and on-site examination of banks and insurance companies. 


\section{Box 1. Recent Legislative and Regulatory Initiatives}

The Financial Intelligence Unit Act of September 14, 2002 established an FIU for the better investigation and prosecution of money laundering and other financial crimes. Under the Act the FIU functions as the Supervisory Authority under the Money Laundering (Prevention) Act, replacing the Central Bank in that role. The Unit is given broad powers to investigate and prosecute financial crimes and to ensure coordination among law enforcement, regulatory bodies government agencies, and private institutions in the prevention and suppression of financial crimes. These powers include authority to require parties to provide information for investigations and prosecutions. These powers also include search authority as well as authority for temporary asset restraint and requests to the court to freeze assets.

The United Nations Resolutions and Conventions (Enforcement) Act 2002 introduced arrangements allowing the use of summary procedures where urgent action is required to freeze funds or financial assets related to terrorism and money laundering.

The Money Laundering (Prevention) (Amendment) Act, 2002 created the offence of terrorism and gave wideranging powers to the Supervisory Authority (now the FIU) to temporarily freeze the funds and financial assets of any person to facilitate an investigation, prosecution or proceeding for a money laundering offence until a court order to freeze such funds can be applied for, as well as to freeze funds where necessary to give effect to a resolution of the Security Council, even without a court order. The amendment also eliminated the need for an MLAT as a condition for providing international legal assistance. The amendment extended the provisions of the anti-money laundering law to encompass international financial services, legal services and accounting services.

On June 23, 2001 the International Financial Services (Code of Conduct) Regulations 2001 were issued introducing mandatory regulations covering due diligence requirements for international financial services providers analogous to the Money Laundering (Prevention) Regulations 1998 issued by the Central Bank as the (at that time) Supervisory Authority for Anti-Money Laundering.

The Offshore Banking (Amendment) Act, 2002 tightened regulation of offshore banks and brought requirements into closer alignment with the requirements imposed on domestic banks. Minimum capital requirements were increased from US\$500,000 to US\$3 million, and the calculation of capital for capital adequacy purposes was tightened. Reserve and liquidity requirements were increased. The threshold for determining control was reduced from 25 percent shareholding to 10 percent. The central bank was given authority to appoint examiners and to charge fees for exams and its enforcement powers were enhanced with new authority to impose fines. The role of the minister in licensing and regulatory decisions was attenuated. For new licensees, the central bank was given discretionary authority to vary the terms and conditions of an offshore bank's license. All secrecy limitations on the authorities' access to bank information were eliminated and their authority to share such information with other authorities was expanded.

In September 2002 the Central Bank for the first time exercised its authority under Part VII of the Banks and Financial Institutions Act to examine a building society.

In the second half of 2002 the Central Bank began publishing abbreviated quarterly financial accounts of domestic banks, along with a comparative table of key ratios. 


\section{E. Strengths and Vulnerabilities in the Financial Regulatory and Supervisory Arrangements}

34. This section gives a brief summary of the findings of the assessments as regards the banking and insurance sectors, and the AML/CFT regime. It also draws together sectoral conclusions on cross-border cooperation and information sharing.

\section{Banking}

35. The Central Bank employs a CAMEL approach to on-site supervision, giving particular attention to credit quality. In the last three or four years considerable attention has been paid to checking for compliance with AML/CFT requirements. Examinations tend to be detailed, focusing on the condition of the bank, but giving less emphasis to various risk factors or the control environment. Explicit enforcement actions are infrequent. However, when a contravention of laws or regulations is detected the Central Bank ensures that this is corrected immediately. Domestic banks are primarily engaged in the traditional areas of deposit taking, loans and foreign exchange of a non-complex nature. Domestic banks appear to be well managed, showing consistent profitability with a relatively low level of nonperforming loans and charge-offs. While the business of international banks is also relatively traditional, for these institutions cross-border cross currency risks are more important. Also, as of August 2003, a few of the banks had common ownership structures with other banks which introduces vulnerabilities that require close attention to the risks running across the group using the tools of consolidated supervision. (Subsequent to the assessment, several steps were taken to strengthen consolidated supervision.) Supervisory practices with respect to the international banks are still evolving, as the longest established firm has only been operating for approximately three years. Recent amendments to the International Banking Act strengthen the authority of the Central Bank to apply supervisory arrangements to international banks that are equivalent to those applied to the domestic banks. Staff turnover and the licensing of new banks has made it difficult for the Central Bank to maintain a steady pace to its examination cycle and in the last year or two the frequency of examinations appears to have lagged. Newly licensed banks, however, are monitored closely. As the supervisor of banks, the Central Bank has responsibility to ensure that banks are in compliance with the anti-money laundering laws. However, establishment of the FIU appears to have led to some staff uncertainty about the division of responsibility between the Central Bank and the FIU.

36. The supervisory and regulatory framework satisfies many of the expectations of the Basel Core Principles but a number of specific weaknesses were identified. Legal and institutional arrangements limit the independence of the Central Bank in supervisory matters vis à vis the Minister, who retains legal authority to make decisions on licensing and enforcement matters. The operations of the Supervisor of Banks would benefit from more autonomous decision making authority within the Central Bank. Recent amendments to the International Banking Act have attenuated the role of the minister with respect to international banks and it would be desirable to extend and reinforce these provisions with respect to domestic banks. Staff shortages and skills weaknesses hamper the Banking 
Supervisor's ability to implement effectively and consistently its program of on-site and offsite supervision. Arrangements for consolidated supervision need to be reinforced as international banks with foreign ownership become more active and as the ownership structures of all banks becomes more complex, with less clear-cut ability to rely on support from an overseas parent. A broader risk based approach to supervision would be desirable as the financial system modernizes and becomes more internationalized.

\section{Insurance}

37. Domestic insurance supervision deals adequately with the traditional and relatively simple products offered in Belize but the assessment noted a variety of deficiencies of domestic insurance supervision relative to the IAIS Core Principles. In general, the domestic insurance industry is small, unsophisticated, risk averse and well disciplined, as evidenced by sustained profitability despite recent high claims due to hurricanes. The Supervisor of Insurance is well versed in insurance regulation and exercises close oversight of the activities of the domestic insurance sector. Regulations and guidance are in place with respect to corporate governance, prudential controls, and market conduct, although several points should be updated. The supervisor's powers are inadequate in several respects, including authority to take immediate action in urgent cases, to approve changes in control, to address fitness and propriety and to share information with other supervisory authorities. Staff weaknesses (a single acting supervisor, supported by an insurance assistant, a registration officer and a secretary) do not allow for a systematic program of on site examinations or offsite monitoring. As an official in a department of the Finance and Home Affairs Ministry, the supervisor does not enjoy full operational autonomy.

38. The Insurance Bill pending before the parliament (and subsequently enacted) addresses many of the legal deficiencies noted in the assessment of domestic insurance supervision, including approval of changes in control, tests for fitness and propriety and exchange of information. In addition, supervision would be strengthened by introducing or updating guidance with respect to corporate governance, internal controls, and market conduct. Supervisory skills with respect to analysis of reinsurance, actuarial valuation, and compliance monitoring should be upgraded. At least two experienced staff should be hired to design and implement an on-site inspection program.

39. Both the business of international insurance and the supervision of international insurance are embryonic. A separate law, the International Insurance Act, governs international insurance and regulation rests with the Supervisor of International Insurance, who is also the Director General of the IFSC. Legislation authorizing international insurance was approved in 1999 but the first licenses for international insurance management were only issued in the first half of 2003, when five firms were licensed. To date, licensing arrangements have been paramount, with attention focused on fit and proper tests for applicants. A formal regulatory regime for on-going supervision of international insurance activities has not yet been brought forward. It is not clear that the two insurers which have been licensed are yet active, or whether there have been some problems in securing 
appropriate reinsurance, perhaps a reflection of the still nascent state of the international insurance sector in Belize.

40. At this stage, the arrangements for supervision of international insurance fall well short of the requirements of the IAIS Core Principles. The IFSC has put in place most of the necessary legislative framework and has made commendable progress in developing subordinate legislation, guidance and codes of conduct. At this stage, however, the Supervisor of International Insurance lacks the staff or specialized expertise to undertake any analysis of business plans, financial projections, or proposed reinsurance. Nor is the supervisor in a position to undertake any ongoing monitoring or on-site inspections.

\section{Anti-money laundering and combating the financing of terrorism (AML/CFT)}

41. With the establishment of the Financial Intelligence Unit Belize now has in place most of the essential legal and institutional arrangements called for in the Methodology. ML is criminalized on the basis of the Vienna Convention and the list of predicate offences excludes some key financial crimes. Obligations under the MLPA, including the obligation to report suspicious transactions, have recently been extended to lawyers and accountants in addition to the other sectors of the financial community that were previously covered. The authority of the FIU to receive suspicious transactions reports and to carry out investigations into financial crime, and to coordinate the flow of information both domestically and internationally has been established under the FIU Act and through amendments to the MILA. Obligations for the various constituents of the financial sector have been spelled out in regulations issued by the Central Bank and by the IFSC, and awareness of ML risks and ML obligations is high.

42. While the essential components of law and regulation called for in the Methodology have been put in place, a number of weaknesses in arrangements remain. Some of these relate to specific gaps in laws and regulation but most relate to coordination gaps among agencies, and incomplete implementation of the regime because of inadequate resources and compliance monitoring, as well as a lack of training.

\section{F. Cross-Border Cooperation and Information-Sharing}

43. The ability to share information and cooperate, both cross-border and domestically, varies significantly across agencies. Under the FIUA, the FIU is required to share information and cooperate with foreign financial intelligence units in the fight against financial crimes and to deal with all requests for legal assistance from foreign countries, law enforcement agencies and other regulatory bodies relating to financial crimes. Also, the FIU has broad powers to require any party to provide any information required to support investigations of financial crime. The financial supervisors, on the other hand are circumscribed both in their ability to access information and to share it. The CBB, for example, can access all bank records and share banking information with banking regulators or outside Belize. Its authority to share with other domestic financial supervisors is not spelled out in legislation and is presently done on an informal basis. The situation with 
respect to insurance is similar to that in banking. The IFSC, on the other hand, has authority to request information from licensed service providers but his authority to share such information with others, at home or abroad, is in doubt.

44. Cooperation between the supervisors and the FIU appears to be good and the FIU is active in responding to information requests from abroad. In general, gateways for information flow should be extended so that information on banking, insurance, mutual funds, managers, administrators and any other information can be transmitted to other regulatory bodies, whether in Belize or cross-border.

\section{G. Key Observations and Recommendations}

45. Several common themes run through the three standards assessments:

- $\quad$ Considerable progress has been made or is in train to update the legal structure for banking and insurance supervision and to strengthen the AML/CFT regime.

- $\quad$ Supervisory arrangements consist of a number of small, separate agencies having responsibility for specific sub sectors of the financial system. Coordination is not always effective.

- $\quad$ The FIU has been energetically launched but teething problems persist with respect to overlapping or shared responsibilities with the financial supervisors on the one hand and law enforcement and the courts, on the other hand.

- $\quad$ Supervisory agencies are overstretched and inadequately resourced in terms of both personnel and skills.

- No agency has the critical mass or the autonomy needed to fully satisfy the expectations of international standards, particularly with respect to on-going oversight of the financial sector.

\section{Streamlining supervision}

46. The separate assessments for banking, insurance and AML/CFT make numerous specific recommendations to improve the existing regulatory arrangements for the financial sector and the existing AML/CFT regime. The Table of Key Recommendations (above) provides a condensed list of the principal recommendations. The mission believes implementation of these recommendations could be made more effective and less costly if the supervisory structure were more streamlined. AML/CFT requirements now apply broadly to virtually all firms and practitioners in the financial system but compliance monitoring by individual supervisors is uneven. Financial institutions have grown and are poised for further development or restructuring but accommodating changes in supervisory arrangements are lagging. Noteworthy in this regard are: (a) the expansion of the credit union sector, particularly the largest association, with new, broad bank-like powers; (b) sidelining of 
building societies, (c) proposed restructuring of DFC; (d) expanding activity of international banks; (e) anticipated launching of international insurance activities and international mutual funds; (f) proposed introduction of an exempt trust registry and more governmental oversight of the IBC Registry; and (g) evolution of the oversight activities of the IFSC.

47. The authorities may wish to consider moving toward some form of a single supervisor. Short of this, the mission recommends that:

- The Central Bank exercises its current authority to conduct examinations of credit unions, at least the larger associations, as has recently been done in the case of building societies. And that the Central Bank be given similar examination authority with respect to the DFC as it is restructured.

- $\quad$ Amendments to the BFIA currently under discussion should complete the harmonization of regulatory requirements for domestic and international banks that was initiated in the recent amendment to the International Banking Act.

- $\quad$ Arrangements for on-going prudential regulation of international insurance be adopted and prudential regulation of all insurance, domestic and international, be combined under a single supervisor.

- $\quad$ The regulatory responsibilities of the IFSC evolve into a more statutory framework rather than the current self-regulatory arrangements, with the capacity for on-going monitoring and enforcement of compliance, as well as clear separating out of the role of private parties from regulatory decisions. An advisory relationship for the private members of the Commission could be modeled on the structure called for in Section 7 of the Mutual Funds Act.

\section{OBSERVANCE OF FINANCIAL SYSTEM STANDARDS AND CODES: REPORTS ON ObSERVANCE OF STANDARDS AND CODES (ROSCs)}

\section{A. Basel Core Principles}

\section{General}

48. The following is a summary of an assessment of compliance by Belize with the Basel Core Principles for Effective Supervision (BCP), which was carried out August 4-15, 2003, in the context of the IMF Offshore Financial Center (OFC) program. The assessment used the Basel Core Principles Methodology document and was prepared by Mr. Joseph Courtright (Banking Supervision Consultant, MFD) and Mr. Peter Kruschel (Banking Supervision Consultant, MFD).

49. The assessment was based in part on a Central Bank self-assessment of compliance with the Core Principles. The mission reviewed relevant laws and regulations, interviewed staff of the Central Bank, and held discussions with representatives of the financial industry. 
The mission would like to acknowledge the excellent cooperation and assistance received from the staff and management of the Central Bank and the financial sector representatives.

\section{Institutional and macroprudential setting, market structure-Overview}

50. Belize has four domestic commercial banks and seven international (formerly offshore) banks. Domestic banks offer demand, savings and term deposits and make demand and term loans to business borrowers as well as lending to individuals including for residential mortgages. Virtually all business is in Belize dollars. Domestic banking in Belize is a straightforward deposit and lending business. International banks are not allowed to take deposits or lend to Belizean residents but may lend in Belize in foreign currency to firms operating in Export Processing Zones (EPZs), Commercial Free Zones (CFZs) and governmental agencies. These firms generate foreign currency in their operations.

51. Total assets of the domestic banks were BZ\$1.25 billion at year-end 2002 with the largest bank, Belize Bank accounting for nearly half. The banking system is quite profitable with a return on assets of 4.7 percent and return on equity of 37 percent. Substantial spreads contribute to the profitability of banks. Net interest income accounts for 75 percent of banking system revenues.

52. Banks must keep 6 percent of deposits in reserves at the $\mathrm{CBB}$ and a further 18 percent of deposits in liquid assets. Certain loans may be counted as liquid assets meaning that the effective minimum level of liquid assets is lower than stated. The CBB closely monitors liquidity. There is no deposit insurance scheme in Belize.

53. International banks have now been in business for several years and two types of business have emerged. The largest international bank raises deposits in U.S. dollars and lends substantially to firms in Export Productions Zones and Commercial Free Zones in Belize. Four of the international banks are owned by or have substantially similar ownership as banking groups from Guatemala, Honduras, and Costa Rica. These banks generally do business in the country of their owners both raising deposits and lending.

54. There are two banking laws in Belize. The Banking and Financial Institutions Act (BFIA) governs domestic banks and the International Banking Act (IBA) applies to international banks. The IBA was originally the Offshore Banking Act (OBA) and did not contain a number of provisions generally found in banking legislation. Amendments to the Act in 2002 added a number of these provisions to the Act as well as changing the name from Offshore to International.

55. The development of the international banking industry in Belize over the past several years together with increased awareness of and effort required in the AML field have challenged the resources of the $\mathrm{CBB}$ in banking supervision and changed the risk profile of the banks it supervises.

56. Belize banks have widely different tax treatments. International banks pay no tax. Two of the domestic banks pay a special low rate of tax, the result of tax arrangements made 
some years ago. Banks and businesses in general in Belize do not pay a corporate income tax but rather a turnover tax on revenues. For banks the tax is calculated on net interest income and other income. Loan losses are not a deductible expense from tax purposes.

\section{General preconditions for effective insurance supervision}

57. Belize is politically stable, with a two party Parliamentary system of Government based on the Westminster model. The legal system is based on common law principles and Belize has a well established, and independent, judiciary. Although, in general, disclosure of corporate financial information is limited, on a quarterly basis the Central Bank publishes condensed balance sheets, income statements and certain financial ratios for domestic banks based on supervisory returns. International accounting standards are followed and competent professional accounting and auditing services are available in Belize.

\section{Main findings}

58. The assessment found that banking supervision complies with or is mostly compliant with most of the Basel core principles. Under current arrangements the minister retains a good deal of discretionary authority with respect to banking supervision but this situation is likely to be modified if a draft bill now under discussion becomes law. Retention of qualified staff is a continuous problem with the result that the intensity of banking supervision varies. With the addition of more international banks and other mergers and expansions, the corporate structures of banks are becoming more complex, requiring greater attention of cross-border and consolidated supervision issues.

59. The following highlights, on a principle-by-principle basis, the main strengths and weaknesses in the banking supervision arrangements for Belize.

\section{Objectives, Autonomy, Powers, and Resources (CP 1)}

60. Prudential regulations are generally sound but the role of the Minister in sometimes detailed supervisory matters is not in keeping with the principle of operational autonomy for supervisors. Recent amendments to the IBA went some way to addressing this but could have gone further.

61. Recent amendments to the IBA now authorize the Supervisor to have access to all information from an international bank and to share information with foreign supervisors as needed. It would be appropriate to provide for a similar information sharing authority with competent domestic authorities and supervisors.

62. Recent recruitment by the Banking Supervision Department has helped address a serious lack of resources. It will take time and training for newer staff to gain experience and become fully effective. 


\section{Licensing and Structure (CPs 2-5)}

63. The CBB licensing process is sound. The CBB has addressed the absence of many necessary prudential and supervisory provisions in the initial international bank act by adding terms and conditions to the licenses of banks. Belize has avoided issuing licenses to shell banks and other questionable operations. The advent of international banks has increased the risk and complexity of the licensing process as the CBB must deal with non local applicants engaged in banking and other businesses within groups sometimes with complex ownership structure. While a few banks were licensed that were in someway parallel to other banks within a group the CBB has now adopted a written policy requiring new international bank applicants to be held by banks within a group. (Following the assessment, additional steps were taken to strengthen consolidated supervision of existing banks.)

\section{Prudential Regulations and Requirements (CPs 6-15)}

64. Rules on capital adequacy, loan classification and provisioning are sound. The rules limiting large loans provide for supervisory approval for lending in excess of 25 percent of capital. Generally supervisors should avoid granting exceptions to well based prudential rules but it is recognized that the small size of the Belize banks means that there will be circumstances in which exposures will be greater than 25 percent of capital. There appears to be little sharing of a credit among Belize banks. This could lead to rather heavy concentrations in portfolios. The rules on lending to parties connected to the bank address only unsecured lending. The matter of all lending to connected parties should be addressed including single and aggregate limits and a requirement that business be done on an arms length basis and that the board approve all transactions.

65. There are no articulated policies or guidelines on country or market risk. While this has not necessarily been a serious deficiency given the apparently small risks in the domestic banking system, the establishment of the international banks with different business and risks means these matters should be addressed.

66. The liquidity requirement for Belize banks has apparently been used as a tool to foster domestic mortgage lending by crediting banks' mortgage holdings towards a portion of the required liquid assets. It would be preferable that prudential requirements for banks do not become mixed with incentives to banks for public policy purposes. (Subsequent to the assessment, a directive issued on April 1, 2004 deleted residential mortgages from this list of other approved liquid assets.)

67. Belize banks generally have sound internal controls and internal audit functions and the $\mathrm{CBB}$ checks and verifies these during its examinations. It would be appropriate for the $\mathrm{CBB}$ to formalize its expectations of banks' internal control and audit functions by issuing a guideline or similar document. Reviews and critiques of banks' internal control and audit during examinations will become more effective as examination staff gain knowledge and experience. 
68. Parallel to the $\mathrm{CBB}$ articulating its requirements for internal controls a guideline or circular should be issued setting out the role and responsibilities of bank directors, as these are the people ultimately responsible for the operation of a bank.

69. CBB supervisors are responsible for checking compliance by banks with preventative measures against money laundering. This process leaves something to be desired due to the infrequency of checks and the procedures used. Checking procedures should be updated to ensure they reflect best practice and a regular schedule of checking carried out. Checking need not only be done at the time of a full examination of a bank.

\section{Methods of Ongoing Supervision (CPs 16-20)}

70. CBB on-site examinations of banks have been less frequent than is desirable. This should improve with the increase in staff in the department although it is recognized that recent recruits will not be fully effective immediately.

71. The CBB examination process focuses appropriately on credit, the major risk in Belize banks. The CBB should review the examination process with an eye to widening the focus on other functions and risks in a bank. The core principles speak of supervisors ensuring that banks have adequate policies, practices, and procedures covering a variety of topics. The possibility of relying on smaller size samples of credits and having more frequent but shorter examinations should be considered. In keeping with an initiative to review the examination process the $\mathrm{CBB}$ could consider regular short visits to banks to speak with management about developments and prospects in the bank's business.

72. The CBB currently receives regular periodic reports from banks that permit it to monitor performance. Recently the $\mathrm{CBB}$ began to publish the quarterly financial results for all domestic banks in Belize. This was useful, as previously only audited annual statements were published. Making this quarterly information public brings Belize into conformity with the practices of supervisors in many other countries and reflects well on Belize. It would be useful if figures for international banks were similarly published.

73. The CBB is aware of the necessity to supervise banks on a consolidated basis. It receives regular financial information from the one subsidiary abroad of a Belize bank as well as the unconsolidated information from the domestic bank. Consolidated financial statements are only provided to the $\mathrm{CBB}$ annually. Although the solo accounts provide useful information, the CBB should also obtain and use consolidated financial information on a more frequent basis.

74. Consolidated supervision is a broad concept that calls for supervisors to look at business groups to which supervised institutions belong in order to assess overall condition and risks, as these will have effects on supervised institutions. The CBB should increase its efforts in this area particularly as several international banks are members of business groups from neighboring countries. For operations within Belize the authority to provide information to and receive information from competent authorities in Belize would facilitate the work. 


\section{Information Requirement (CP 21)}

75. The CBB ensures through on-site examinations that each bank maintains adequate records drawn up with consistent accounting standards and that there are open communication lines with the external auditors.

\section{Formal Powers of Supervisors (CP 22)}

76. The two Belize banking acts contain an adequate set of authorities for the supervision of banks. These authorities include the canceling of the license of a bank, removing directors and officers, giving specific instructions to a bank to do or cease to do something and topping the payment of dividends. There is no consistency in the acts regarding the role of the Minister. The Minister is always involved in these actions in the case of international banks but only in some actions for domestic banks. It would be preferable for the same treatment under the same conditions to attach to both domestic and international banks.

\section{Cross-Border Banking (CPs 23-25)}

77. Belize is both a home and host country supervisor. Belize has established contact and agreements with the supervisors in the jurisdictions in which its banks operate, and the jurisdictions from which some of its recently incorporated international banks come. MOUs have been signed with some supervisors and others are being developed.

78. The growth in the business by international banks in jurisdictions outside Belize requires that Belize continue to foster its relationships, and exchanges of information, with foreign supervisors. The CBB is moving to strengthen supervision by discouraging parallel bank structures and encouraging that these be restructured so that international banks in Belize are held by the bank within the parent group. These are useful and appropriate steps.

Table 2. Recommended Action Plan to Improve Compliance of the Basel Core Principles

\begin{tabular}{|l|l|}
\hline \multicolumn{1}{|c|}{ Reference Principle } & \multicolumn{1}{c|}{ Recommended Action } \\
\hline $\begin{array}{l}1.2 \text { - Operational Independence and Adequate } \\
\text { Resources }\end{array}$ & $\begin{array}{l}\text { Amend both the BFIA and IBA to reduce the role of the } \\
\text { Minister in supervisory matter and have the same provisions in } \\
\text { each act.(Proposals were developed following the assessment.) } \\
\text { Engage further staff in BSSD and train staff through a variety } \\
\text { of courses, visits, on the job and working with an Advisor. }\end{array}$ \\
\hline $\begin{array}{l}\text { 1.4 - Powers to address compliance with laws as } \\
\text { well as safety and soundness concerns. }\end{array}$ & $\begin{array}{l}\text { Amend both BFIA and IBA to authorize sharing of information } \\
\text { with domestic authorities in Belize. Amend other Belize Acts to } \\
\text { authorize other competent authorities to share with CBB. }\end{array}$ \\
\hline 1.5 - Legal protection for supervisors & $\begin{array}{l}\text { Amend BFIA to clarify that CBB staff are protected from legal } \\
\text { action when carrying out their duties. }\end{array}$ \\
\hline 1.6 - Arrangements for sharing information & See 1.4 above \\
\hline - Licensing & See 1.2 above \\
\hline
\end{tabular}




\begin{tabular}{|c|c|}
\hline Reference Principle & Recommended Action \\
\hline 9 - Large Exposure Limits & $\begin{array}{l}\text { Apply 6X capital limit to the aggregate of exposures over } 10 \\
\text { percent of capital rather than exposures over } 25 \text { percent of } \\
\text { capital. Reconsider absence of any aggregate limit on large } \\
\text { exposures in IBA. }\end{array}$ \\
\hline 10 - Lending to parties related to the bank & $\begin{array}{l}\text { Amend both Acts to require connected lending be on arms } \\
\text { length terms and that Board approval be given. Address limits } \\
\text { on connected party exposure (secured and unsecured) for } \\
\text { individual exposures and aggregate of all connected party } \\
\text { lending. }\end{array}$ \\
\hline 11 - Country Risk & Address country risk for international banks. \\
\hline 12 - Market Risk & Address market risk \\
\hline 13 - Other Risks & $\begin{array}{l}\text { Separate liquidity requirements from measures designed to } \\
\text { foster lending for residential mortgages.(Directive issued April } \\
1,2004) \\
\text { Collect information from banks on maturities of assets and } \\
\text { liabilities. }\end{array}$ \\
\hline 14 - Internal Control and Audit & $\begin{array}{l}\text { Issue circular on responsibilities of directors. } \\
\text { Issue circular on Internal Control. } \\
\text { Foster contact with Internal Auditors, External Auditors }\end{array}$ \\
\hline 15 - Money Laundering & $\begin{array}{l}\text { More frequent checks of banks. Develop a detailed } \\
\text { questionnaire. Work with the FIU to strengthen guidance notes } \\
\text { and regulations to take full account of the Basle Committee } \\
\text { paper on customer due diligence. Periodic training for CBB } \\
\text { staff at all levels on AML and CFT. }\end{array}$ \\
\hline 16 - On and Off-site Supervision & $\begin{array}{l}\text { Training and experience for examiners. } \\
\text { Review examination process with an eye to more frequent } \\
\text { visits, perhaps shorter visits. Broaden focus from credit review } \\
\text { work and also review and assess banks' processes. }\end{array}$ \\
\hline 17 - Bank Management Contact & $\begin{array}{l}\text { Contact bank management more frequently on a regular basis. } \\
\text { Train staff in understanding banks from a banker's point of } \\
\text { view. }\end{array}$ \\
\hline 18 - Off-site Supervision & $\begin{array}{l}\text { Have banks report consolidated figures on a more frequent } \\
\text { basis.(Reporting requirements were expanded effective March } \\
\text { 31, 2004.) }\end{array}$ \\
\hline 20 - Consolidated Supervision & $\begin{array}{l}\text { Develop knowledge and understanding of groups that own } \\
\text { banks, particularly international banks. Understand intergroup } \\
\text { transactions. Identify risks. Determine whether things can be } \\
\text { done to reduce risks to the bank. }\end{array}$ \\
\hline 21 - Accounting and Disclosure & $\begin{array}{l}\text { Publish international bank financial figures as is done with local } \\
\text { bank figures. Amend Act if required. }\end{array}$ \\
\hline 22 - Remedial Measures & $\begin{array}{l}\text { See } 1.2 \text { Amend IBA to parallel FBIA and remove Minister from } \\
\text { the process of requiring a bank to take remedial measures }\end{array}$ \\
\hline 24 - Host Country Supervision & $\begin{array}{l}\text { Consider publicly enunciating policy of no parallel banks and } \\
\text { requirement that banks are held by the bank within any group. } \\
\text { (Licensing guidelines for international banks, including a } \\
\text { requirement that banks be held by the bank within a group, } \\
\text { were issues subsequent to the assessment.) }\end{array}$ \\
\hline
\end{tabular}




\section{Authorities' response}

The Authorities agree with the report and most of the assessments of the Basel Core Principles. The Authorities will take the necessary steps to implement the recommendations submitted by the IMF.

The Central Bank has taken steps to strengthen the Financial Sector Supervision Department. As of 10 December 2003 an IMF Technical Advisor has joined the Department. Belize has also obtained funding from the Inter-American Development Bank to strengthen banking and non-banking supervision. This entails: 1) revamping legislation and issuance of regulations on regulatory and supervisory issues, 2) training of bank examiners, and 3) upgrading the information system by purchasing computers and software as well as implementing an electronic database on all financial institutions.

Below is Belize's Action Plan to address the issues cited in the report.

\section{Belize Action Plan to Improve Compliance with the Basel Core Principles}

\begin{tabular}{|c|c|}
\hline Reference Principle & Planned Action \\
\hline $\begin{array}{l}1.2 \text { - Operational Independence and Adequate } \\
\text { Resources }\end{array}$ & $\begin{array}{l}\text { Both the BFIA and IBA will be revisited. The first draft is } \\
\text { expected by the end of } 2004 \text {. } \\
\text { The new examiners attended the Bank Analysis and the } \\
\text { Credit Risk Analysis Courses offered by the Federal Reserve } \\
\text { Bank. Examiners also attended the Problem Bank Course } \\
\text { offered by the OCC. } \\
\text { An IMF Advisor has joined the FSSD to assist in the } \\
\text { strengthening of the department. }\end{array}$ \\
\hline $\begin{array}{l}1.4 \text { - Powers to address compliance with laws } \\
\text { as well as safety and soundness concerns. }\end{array}$ & $\begin{array}{l}\text { The proposed amendments will allow the sharing of } \\
\text { information among domestic authorities. }\end{array}$ \\
\hline 1.5 - Legal protection for supervisors & The proposed amendments will address this issue. \\
\hline 1.6 - Arrangements for sharing information & See 1.4 above \\
\hline 3 - Licensing & $\begin{array}{l}\text { The proposed amendments will allow the CBB to issue and } \\
\text { revoke a license. }\end{array}$ \\
\hline 9 - Large Exposure Limits & $\begin{array}{l}\text { As of June } 2004 \text {, the CBB will commence the gathering of } \\
\text { information on exposure of } 10 \% \text { or greater in order to } \\
\text { evaluate the loan portfolio for concentration. }\end{array}$ \\
\hline 10 - Lending to parties related to the bank & $\begin{array}{l}\text { This will be addressed in the proposed amendments. In } \\
\text { addition, detailed regulations on lending to related parties } \\
\text { will be issued under both Acts. This is expected to be issued } \\
\text { by the end of } 2004 \text {. }\end{array}$ \\
\hline 11 - Country Risk & This will be addressed by 2005 for international banks. \\
\hline 12 - Market Risk & This will be addressed by 2005 . \\
\hline
\end{tabular}




\begin{tabular}{|c|c|}
\hline Reference Principle & Planned Action \\
\hline 13 - Other Risks & $\begin{array}{l}\text { On } 1 \text { April 2004, the CBB issued a directive that addressed } \\
\text { this issue. } \\
\text { The CBB has requested that both domestic and international } \\
\text { banks submit information on maturities of assets and } \\
\text { liabilities on a quarterly basis commencing in June } 2004 \text {. }\end{array}$ \\
\hline 14 - Internal Control and Audit & $\begin{array}{l}\text { Guidance notes/regulations for Corporate Governance and } \\
\text { Internal Controls will be issued early } 2005 \text {. }\end{array}$ \\
\hline 15 - Money Laundering & $\begin{array}{l}\text { In January 2004, the FIU conducted AML training for the } \\
\text { financial sector. In February 2004, the IMF conducted a } \\
\text { workshop with regulators on how to conduct anti-money } \\
\text { laundering examinations. } \\
\text { The CBB conducted Anti-Money Laundering examinations } \\
\text { on three banks and expects to visit the remaining banks by } \\
\text { mid } 2005 \text {. } \\
\text { The CBB will also collaborate with the FIU in regards to the } \\
\text { guidance notes and regulations for anti-money laundering. }\end{array}$ \\
\hline 16 - On and Off-site Supervision & $\begin{array}{l}\text { The CBB continues to train FSSD staff as mentioned in item } \\
1.2 \text { above and the IMF Advisor is assisting in implementing } \\
\text { Risk Focused Supervision. } \\
\text { The CBB conducted its first Risk Focused Supervision in } \\
\text { June } 2004 \text {. }\end{array}$ \\
\hline 17 - Bank Management Contact & $\begin{array}{l}\text { The CBB is contacting bank management more frequently } \\
\text { and the IMF Advisor will train FSSD staff in understanding } \\
\text { banks from a banker's point of view. }\end{array}$ \\
\hline 18 - Off-site Supervision & $\begin{array}{l}\text { The CBB has requested consolidated data from the } \\
\text { respective banks as of March } 2004 \text {. }\end{array}$ \\
\hline 20 - Consolidated Supervision & $\begin{array}{l}\text { The IMF Advisor will be conducting workshops regarding } \\
\text { consolidated supervision. }\end{array}$ \\
\hline 21 - Accounting and Disclosure & $\begin{array}{l}\text { The IBA does not allow the CBB to publish individual bank } \\
\text { data. In the interim, a letter will be sent to each bank } \\
\text { requesting permission to place their balance sheet and } \\
\text { income statements on CBB's web site. } \\
\text { Nevertheless, the IBA will be amended to allow the } \\
\text { individual bank data can be published. }\end{array}$ \\
\hline 22 - Remedial Measures & See comment on 1.2 above. \\
\hline 24 - Host Country Supervision & $\begin{array}{l}\text { Once a bank is part of a group of investors applying for a } \\
\text { banking license the CBB requires that the bank owns the } \\
\text { proposed bank. }\end{array}$ \\
\hline
\end{tabular}




\section{B. IAIS Insurance Core Principles ${ }^{2}$}

\section{General}

79. The assessment of the insurance sector was performed as part of an OFC assessment for Belize. The main objectives of the assessment were to determine the levels of observance with the International Association of Insurance Supervisors (IAIS) Principles, and to suggest areas where further development may be appropriate.

80. There is a difference in focus between the IAIS Principles, geared towards supervisors who undertake supervision of domestic and international insurance business under a single legislative and administrative framework, and the system adopted in Belize where domestic and international insurance are regulated and supervised under different legislation and by different authorities. This has necessitated separate assessments of the two systems.

81. The review of Belize' observance of the IAIS Core Principles involved the analysis of the self-assessments prepared by the Belize Office of the Supervisor of Insurance and by staff of the Supervisor of International Insurance, and a review of the insurance laws and other relevant official documents. Meetings were held with the Acting Supervisor of Insurance and with the Supervisor of International Insurance. In addition a number of insurance companies were interviewed to gain some insight into the operation of the Belize insurance markets.

\section{Institutional and macroprudential setting — Overview}

\section{Domestic insurance}

82. The domestic market is very small. There are 17 insurance firms and one association of underwriters licensed to write insurance business in Belize. Six are life insurance companies, nine are general companies, and three are composites. Of these, one life companies and one composite are closed to new business. There are no reinsurance companies operating within Belize and Belize insurers are wholly dependent on external reinsurers for cover

83. At the end of 2001, the industry had BZ\$89.3 million in assets. Of this, some BZ\$7.6 million was held as statutory deposits by the Office of the Supervisor of Insurance, mainly as cash, deposits, defense bonds, and treasury bills. Liabilities amounted to BZ\$55 million. Gross written premiums amounted to BZ\$60.9 million.

84. Domestic Insurance in Belize is largely based on traditional and relatively simple products. It has significant exposure to catastrophe losses (hurricanes) but most of this risk is

\footnotetext{
${ }^{2}$ This IAIS core principles assessment was prepared by Mr. Martin Roberts (Consultant, Insurance, MFD).
} 
passed offshore through reinsurance. The industry's resilience to major claims, and the effectiveness of its reinsurance protections were tested by Hurricane "Keith" (October 1, 2000). Total claims arising from Keith amounted to BZ\$59.5 million of which only BZ\$7.4 million was retained in Belize. By December 31, 2002, all claims had been settled with no reported reinsurance non-performance.

\section{International insurance}

85. The legislation allows the registration of life and non life insurers and, applies substantially the same regime to re-insurers as to other insurers. At the time of the assessment only five companies had been registered in the field of international insurance; two international insurers (both non-life); two insurance managers, and one principal insurance representative. It is not clear that any of these are yet active.

\section{Supervisory authorities and governing legislation}

\section{Office of the Supervisor of Insurance (domestic)}

86. The domestic insurance industry is regulated by the Insurance Act (Revised 2000). Chapter 251 (Revised 2000) provides for administration of the Act by the Supervisor of Insurance under the direction of the Minister. The Supervisor of Insurance is responsible for the registration and supervision of the domestic insurance industry. Although the office was created by the 1976 Insurance Act, the post of Supervisor of Insurance was only made a full time one in 2000. The present Acting Supervisor, who was appointed to her post at that time, had worked full time on insurance matters since 1998, and part time since 1992.

\section{International insurance supervisor (international)}

87. The 1999 International Insurance Act governs offshore insurance business. The Act allows for the appointment of a Supervisor of International Insurance, responsible for registering and supervising international insurance companies. The Supervisor operates under the aegis of the International Financial Services Commission (IFSC), of which, as Director General, he is a member. He is supported by one assistant and both he and his assistant have secretarial support. Neither the International Insurance Supervisor, nor his assistant, work full time on insurance matters (the Supervisor estimates that it accounts for about 25 percent of their time), and neither have specialist expertise in insurance (both are qualified lawyers).

\section{General preconditions for effective insurance supervision}

88. Belize is politically stable, with a two party Parliamentary system of Government on the Westminster model. It has a well established, and independent, judiciary. Traditions of public disclosure of corporate financial information are not yet well established - although insurance accounts provided to the Office of Insurance Supervision are publicly obtainable on payment of a fee. 
89. Insurance expertise in Belize is limited - the industry is not large enough to support specialist auditors and there are no actuaries practicing in Belize.

90. There are no guarantee fund arrangements to protect policyholders in the event of an insurance company failure. However the Office of the Supervisor of Insurers holds statutory deposits which may be used to meet claims in the event of default.

91. Nonetheless against the background of the relatively small, and highly traditional, domestic industry, and the as yet undeveloped international industry, the essential preconditions for effective supervision are met.

\section{Main findings}

\section{Regulation and supervision of the domestic market}

92. The legislation governing licensing and on-going supervision is deficient in a number of respects. This is recognized by the Belize authorities and new legislation has been drafted and published and will be introduced into parliament shortly. When this legislation is enacted it will produce a significant improvement in the current level of observance. (A new Insurance Act was enacted in March 2004, subsequent to the drafting of this report.)

93. The Office of the Supervisor of Insurance is not well resourced and it would be desirable that it should be reinforced to allow it to undertake a program of regular on-site inspections as well as making some additional analysis of companies' gross and net exposures and the adequacy of their reinsurance protections.

94. The Supervisor has regular informal contacts with the industry and undertakes a systematic analysis of annual financial returns, and - a recent innovation — of more limited financial data provided quarterly. New product particulars are considered by the Supervisor before being introduced to the market. A requirement that insurance intermediaries be registered has recently been introduced, and the opportunity taken to weed out some who do not meet appropriate standards. Overall while, as noted, some improvements and an increase in resources would be desirable, supervision of the domestic insurance market is generally "fit for purpose" having regard to its size and the stage of its development.

95. A principle-by-principle analysis of observance of the IAIS Core Principles shows that:

\section{Organization of insurance supervisor CP 1 (domestic)}

96. The powers currently provided to the Supervisor are inadequate, particularly in not allowing for immediate action to be taken in urgent cases. No legal protection is provided to the Supervisor or the Staff of the Supervisor's office. (These deficiencies are addressed in the Insurance Act passed in March 2004.) 
97. The Office of the Supervisor lacks the resources necessary to undertake regular onsite inspections and to do a fully comprehensive analysis of companies' financial positions.

\section{Licensing and changes in control CPs 2-3 (domestic)}

98. The current legislation suffers a number of deficiencies:

- It does not address issues of fitness and propriety.

- It does not prohibit the licensing of composite insurers.

- It does not give the Supervisor adequate powers in relation to changes in control.

- It does not provide for the sharing of information with other supervisory authorities.

99. These shortcomings are addressed in the new Insurance Act. It should be recognized that, if advantage is to be taken of the new powers and functions, the necessary resources will need to be made available.

\section{Corporate governance and internal controls CPs 4-5 (domestic)}

100. In the absence of detailed corporate governance rules under general company law, the Supervisor should set appropriate standards and put in place procedures for monitoring compliance. More attention is also needed to internal controls.

\section{Prudential rules CPs 6-10 (domestic)}

101. Regulations are in place limiting the admissibility of assets for solvency purposes, although it would be desirable that these be expanded in guidance notes and that insurers be required to submit details of their investment policy to the Supervisor. On the liability side the current requirement that companies writing long-term business should conduct a quinquennial actuarial valuation is inadequate: this should be replaced by a requirement for an actuarial review at least every three years. (A requirement for a three year actuarial review has been included in the new Act.)

\section{Market conduct CP 11 (domestic)}

102. Comprehensive rules are in place, although these could usefully be supplemented by guidance. Action is in hand to raise standards among intermediaries, but consideration should be given to more pro-active monitoring of compliance.

\section{Monitoring, inspection, and sanctions CPs 12-14 (domestic)}

103. Current resources do not allow regular on-site inspections to be undertaken, and limit the extent to which a detailed analysis of companies' financial position, and particularly of their reinsurance arrangements can be made. At present the sanctions available to the 
Supervisor are limited and there is no power to take immediate action in urgent cases. These latter shortcomings are addressed in the new Insurance Act.

\section{Cross-border business operations, coordination, cooperation, and confidentiality CPs 15-17 (domestic)}

104. The Acting Supervisor has established a good network of international contacts. However the current legislation does not facilitate international cooperation and information sharing. This is addressed in the new Insurance Act.

\section{Regulation and supervision of the international market}

105. Both the industry and the supervisory regime are at a very early stage of development. The IFSC has put in place most of the necessary legislative framework, and has made commendable progress in developing subordinate legislation, guidance and codes of conduct. However, some significant gaps remain (in relation to which recommendations are set out in the action plan). Effective arrangements have been put in place to allow appropriate due diligence to be carried out in relation to those applying for registration.

106. Of major concern however, is the lack of technical insurance resources within the IFSC. As things stand, the Supervisor relies on outside consultants to undertake any analysis of the business plans, financial projections, proposed reinsurance protections which the legislation (rightly) requires to be submitted to the Supervisor to support applications for registration. Also the supervisor is not in a position to undertake any ongoing financial monitoring or on-site inspections.

107. It is recognized that, at a time when the international industry is not yet active the recruitment of a specialist team able to carry out these functions would raise significant cost/benefit issues. However the dangers of inadequate scrutiny of applications for registration are evident. The action plan suggests ways in which this problem might be cost effectively addressed.

108. A principle-by-principle analysis of observance of the IAIS Core Principles shows that:

\section{Organization of insurance supervisor CP 1 (international)}

109. The Supervisor faces a serious problem in the lack of technical insurance skills noted above.

\section{Licensing and changes in control CPs 2-3 (international)}

110. Again the lack of technical skills available to support assessment of application for registration presents a major problem. Additionally, changes of control do not require prior approval from the Supervisor (although they do have to be notified after the event). No procedures are yet in place for considering changes in control. 


\section{Corporate governance and internal controls CPs 4-5 (international)}

111. In the absence of detailed corporate governance rules under general company law, the Supervisor should set appropriate standards and put in place procedures for monitoring compliance. More attention is also needed to internal controls. The legislation permits the Supervisor, when registering a company, to attach conditions to which the company will be subject and may subsequently impose additional conditions where appropriate. Such conditions could extend to specifying appropriate internal controls. However no policy or procedures have yet been developed, and licenses so far issued have not contained significant conditions in relation to internal controls.

\section{Prudential rules CPs 6-10 (international)}

112. Regulations are in place limiting the admissibility of assets for solvency purposes (but not yet for the determination of liabilities which are subject only to the requirements of accepted accounting and actuarial practice). The legislation also provides for the maintenance of specified solvency margins. It would be desirable that these rules be supplemented by rules governing diversification of assets, asset/liability matching and liquidity; the determination of liabilities, and that consideration be given to ways in which the solvency requirements might be made more risk-sensitive.

\section{Market conduct CP 11 (international)}

113. Reasonably comprehensive rules are in place. Consideration should be given to more pro-active monitoring of compliance.

\section{Monitoring, inspection, and sanctions CPs 12-14 (international)}

114. Lack of technical expertise prevents effective financial monitoring, so that the supervisor is wholly reliant on certification by auditors and independent actuaries. It is not clear that adequate powers exist to allow routine on site inspections to be undertaken. Appropriate sanctions are available to the Supervisor, but there is no power to take immediate action in urgent cases

\section{Cross-border business operations, coordination, cooperation, and confidentiality}

\section{CPs 14-17 (international)}

115. Appropriate legislative provisions exist in all these areas. It would be desirable for the Supervisor to establish closer relations with other insurance supervisory authorities through greater participation in the work of and the training opportunities presented by, the relevant international bodies. 
Table 3. Recommended Action Plan to Improve Observance of IAIS Insurance Core Principles-Domestic Insurance

\begin{tabular}{|c|c|}
\hline Reference Principle & Recommended Action \\
\hline \multicolumn{2}{|l|}{$\begin{array}{l}\text { Organization of an Insurance Supervisor } \\
\text { i.e., CP } 1\end{array}$} \\
\hline & $\begin{array}{l}\text { The main need here is for more effective powers, for legal protection } \\
\text { and for additional resources_primarily to allow more intensive } \\
\text { supervision, including through on-site inspections and through more } \\
\text { systematic and thorough evaluation of companies' gross exposures, } \\
\text { retention levels and reinsurance protections. } \\
\text { The legal issues will be adequately addressed if the Insurance Bill is } \\
\text { enacted as drafted. } \\
\text { At least two experienced staff should be hired to design and } \\
\text { implement an on-site inspection program. The Acting Supervisor } \\
\text { should be involved in the selection of new staff so that their aptitude } \\
\text { for this specialist work can be assessed. } \\
\text { Staff should receive all the training necessary to have a greater } \\
\text { understanding of reinsurance issues. } \\
\text { Guidance should be issued to the industry on supervisory expectations } \\
\text { and standards. The "Practitioners Code" issued by the IFSC would } \\
\text { proved a good model, if suitably adapted. }\end{array}$ \\
\hline $\begin{array}{l}\text { Licensing and Changes in Control } \\
\text { i.e., CPs 2-3 }\end{array}$ & $\begin{array}{l}\text { Application forms should be included in the Insurance (Account and } \\
\text { Form). Regulations and the definition of "fit and proper" should be } \\
\text { provided in the law. These might conveniently follow those } \\
\text { developed by the IFSC for use with international companies. } \\
\text { Prior regulatory consent should be required before changes of control } \\
\text { take place. (The Insurance Act addresses this issue.) }\end{array}$ \\
\hline $\begin{array}{l}\text { Corporate Governance and Internal Controls } \\
\text { i.e., CPs 4-5 }\end{array}$ & $\begin{array}{l}\text { Guidance notes should be issued that require the Boards of Directors } \\
\text { of licensed institutions to address compliance with corporate } \\
\text { governance principles. } \\
\text { Guidance notes on appropriate internal controls should be issued to } \\
\text { institutions. These should outline minimum standards that the } \\
\text { supervisor deems necessary, including standards for monitoring } \\
\text { underwriting risks, claims responsibilities, compliance with the law, } \\
\text { fair treatment of customers and anti-money laundering requirements. } \\
\text { Consideration should be given to a requirement that company auditors } \\
\text { report annually, together with providing their audit opinion on the } \\
\text { accounts, on the adequacy of the company's systems and controls, } \\
\text { identifying any areas of weakness. }\end{array}$ \\
\hline
\end{tabular}




\begin{tabular}{|c|c|}
\hline Reference Principle & Recommended Action \\
\hline $\begin{array}{l}\text { Prudential Rules } \\
\text { i.e., CPs 6-10 }\end{array}$ & $\begin{array}{l}\text { Consideration should be given to reducing the six month period } \\
\text { allowed for the submission of returns, or as a minimum, the industry } \\
\text { should be warned that requests for extension of the six month } \\
\text { deadline will only be granted exceptionally. (The new Act changed } \\
\text { the six month period to four months.) } \\
\text { The requirement for actuarial valuation for long-term business should } \\
\text { be for triennial, rather than quinquennial reviews. The Act should be } \\
\text { amended to allow the Supervisor to appoint an independent actuary, at } \\
\text { the expense of the company, to perform an independent actuarial } \\
\text { study. (The new Act changed the actuarial review period from five } \\
\text { years to three years.) } \\
\text { Insurers should submit additional details of their reinsurance } \\
\text { arrangements and their reinsurers as a matter of routine; these should } \\
\text { include a statement of its major treaty and facultative reinsurers; } \\
\text { premiums payable to the reinsurers; anticipated recoveries; deposits } \\
\text { received from the reinsurers, and details of any connection between } \\
\text { the insurer and any of its reinsurers. } \\
\text { A full analysis of the reinsurance program should be performed, } \\
\text { particularly an examination of the per risk maximum retention relative } \\
\text { to capital and surplus. }\end{array}$ \\
\hline $\begin{array}{l}\text { Market Conduct } \\
\text { i.e., CP } 11\end{array}$ & $\begin{array}{l}\text { A review of regulatory practices with respect to intermediaries should } \\
\text { be carried out particularly to determine how to monitor compliance } \\
\text { effectively. }\end{array}$ \\
\hline $\begin{array}{l}\text { Monitoring, Inspection, and Sanctions } \\
\text { i.e., CPs 12-14 }\end{array}$ & $\begin{array}{l}\text { A fully documented and structured on-site program should be } \\
\text { developed and a comprehensive inspection manual which includes } \\
\text { anti-money laundering procedures, compliance and internal control } \\
\text { issues, underwriting and claim practices, reinsurance, accounting, } \\
\text { corporate governance as well as capital adequacy and investment } \\
\text { management. } \\
\text { It would be desirable that a guidance note be developed, and that } \\
\text { companies be required to describe their investment policy when filing } \\
\text { their annual return. }\end{array}$ \\
\hline
\end{tabular}


Table 4. Recommended Action Plan to Improve Observance of IAIS Insurance Core Principles-International Insurance

\begin{tabular}{|c|c|}
\hline Reference Principle & Recommended Action \\
\hline \multicolumn{2}{|l|}{$\begin{array}{l}\text { Organization of an Insurance Supervisor } \\
\text { CP } 1\end{array}$} \\
\hline & $\begin{array}{l}\text { The Supervisor should, as a matter of urgency, acquire the resources } \\
\text { necessary to understand and assess potentially complex insurance } \\
\text { operations; the viability of their business plans, the adequacy of their } \\
\text { resources to carry out these plans, and the appropriateness and strength } \\
\text { of their reinsurance programs-having regard to the nature and range } \\
\text { of business written and their resilience to potential adverse } \\
\text { developments, and to carry out on-site inspections. In the short term, } \\
\text { and having regard to the very early stage of development of this sector } \\
\text { of the industry, it may be appropriate for this assessment to be } \\
\text { outsourced to suitably experienced insurance experts. If an outsourcing } \\
\text { route is chosen the IFSC should have at least one member of staff with } \\
\text { the necessary financial skills to act as an "intelligent customer." Any } \\
\text { provider of outsourced advice should be accountable solely to the IFSC } \\
\text { and should have no connection (whether as auditors or otherwise) with } \\
\text { any of the companies in relation to whom they provide advice. } \\
\text { Given the technical complexity of the regulations, etc. that are still } \\
\text { needed to complete the legislative framework consideration should also } \\
\text { be given to providing additional and specialist resource to the } \\
\text { Supervisor of International Insurance for this purpose-again through } \\
\text { outsourcing if appropriate. }\end{array}$ \\
\hline \multicolumn{2}{|l|}{$\begin{array}{l}\text { Licensing and Changes in Control } \\
\text { CPs 2-3 }\end{array}$} \\
\hline & $\begin{array}{l}\text { See recommendations as to resourcing noted under Principle } 1 . \\
\text { In addition: } \\
\text { - Current requirements as to minimum paid up share capital should } \\
\text { be reviewed, and brought into line, at the least, to those specified } \\
\text { for domestic insurance companies in the new Insurance Act. } \\
\text { - Reinsurers should be subject to the same requirements as insurers. } \\
\text { - Changes in control should be subject to prior consent by the } \\
\text { Supervisor who should establish appropriate procedures for this } \\
\text { purpose. }\end{array}$ \\
\hline \multicolumn{2}{|l|}{$\begin{array}{l}\text { Corporate Governance and Internal Controls } \\
\text { i.e., CPs 4-5 }\end{array}$} \\
\hline & $\begin{array}{l}\text { Guidance should be issued on appropriate standards of corporate } \\
\text { governance. } \\
\text { Guidance should be issued on the Supervisor's expectations as to the } \\
\text { systems and controls he would expect to see in place in registered } \\
\text { international insurers (which should include controls over downside } \\
\text { risks from the use of derivatives). The Supervisor should consider } \\
\text { whether the adequacy of systems and controls should be made the } \\
\text { subject of a regular report by the auditor. }\end{array}$ \\
\hline
\end{tabular}




\begin{tabular}{|c|c|}
\hline Reference Principle & Recommended Action \\
\hline \multicolumn{2}{|l|}{$\begin{array}{l}\text { Prudential Rules } \\
\text { i.e., CPs 6-10 }\end{array}$} \\
\hline & $\begin{array}{l}\text { The IFSC should complete the legislative framework, including by } \\
\text { making the remainder of regulations envisaged in Section } 39 \text { of the } \\
\text { International Insurance Act, including in particular regulations } \\
\text { governing the valuation of liabilities and the form and content of } \\
\text { accounts and statements to be submitted to the supervisor. The } \\
\text { regulations on asset valuation for solvency purposes should be } \\
\text { extended to cover requirements for diversification, for asset liability } \\
\text { matching and for liquidity. Guidance should be issued on the way in } \\
\text { which the Supervisor would expect to exercise his discretion to } \\
\text { disallow assets for solvency purposes, e.g., to ensure adequate } \\
\text { diversification. } \\
\text { Consideration should be given to introducing greater risk sensitivity } \\
\text { into the solvency regime-either through class enhancement of } \\
\text { minimum margin requirements, or through risk sensitive capital } \\
\text { charges. }\end{array}$ \\
\hline \multicolumn{2}{|l|}{$\begin{array}{l}\text { Market Conduct } \\
\text { i.e., CP } 11\end{array}$} \\
\hline & $\begin{array}{l}\text { The Supervisor should consider adopting a more pro-active approach to } \\
\text { the monitoring of standards of market conduct. }\end{array}$ \\
\hline \multicolumn{2}{|l|}{$\begin{array}{l}\text { Monitoring, Inspection, and Sanctions } \\
\text { i.e., CPs 12-14 }\end{array}$} \\
\hline & $\begin{array}{l}\text { See recommendations as to resourcing noted under Principle } 1 . \\
\text { In addition: } \\
\text { - Powers should be given allowing the Supervisor to take immediate } \\
\text { action (i.e., without the need for prior notice) in urgent cases. } \\
\text { The Supervisor should review the adequacy of his powers to } \\
\text { undertake, or to commission, routine on-site inspections in cases } \\
\text { where the grounds to appoint an inspector are not met. }\end{array}$ \\
\hline \multirow[t]{2}{*}{$\begin{array}{l}\text { Cross-Border Operations, Supervisory } \\
\text { Coordination and Cooperation, and Confidentiality } \\
\text { i.e., CPs 15-17 }\end{array}$} & \\
\hline & $\begin{array}{l}\text { The Supervisor should consider taking a more active part in relevant } \\
\text { international bodies both to facilitate more effective cooperation on a } \\
\text { pro-active basis and also as an aid to establishing and maintaining } \\
\text { insurance supervisory expertise. } \\
\text { Consideration should be given to extending confidentiality protection } \\
\text { to all information provided by another supervisory authority without } \\
\text { the need for a specific request. }\end{array}$ \\
\hline
\end{tabular}

\section{Domestic insurance authorities' response}

The Belize authorities appreciate the comprehensive assessment by the IMF of the present arrangements for the supervision of the domestic insurance sector, including the constructive recommendations for strengthening insurance supervision and for adhering more closely to the IAIS principles. Several initiatives are underway to respond to these suggestions. 
An Insurance Act was enacted in March 2004. This legislation will address many of the shortcomings in the legal framework that were identified in the assessment. Key features include:

- The Insurance Act contains provisions for the legal protection of the Supervisor of Insurance (SOI) in the exercise of his/her duty. Adequate funds are provided for OSI to meet present operations and will also be made available for the expanded functions, duties and responsibilities as required by the Insurance Bill.

- Regulations make provisions for guidelines to be issued in respect of business plans, etc. In practice, OSI has implemented the requirement of Biographical Affidavits (which includes a Police Report) and have issued Guidelines for Business Plans which are required for registration application.

- Fit \& proper criteria and changes in control are included in the Insurance Bill.

- The Insurance Act contains provision for the triennial actuarial evaluation and gives SOI the power to request an evaluation at shorter intervals on a case by case basis if deemed necessary.

- The Insurance Act contains provisions for sanctions - through administrative penalties and by summary conviction. The SOI will now have the power to take quick and effective enforcement actions.

In addition, under existing legislation, the OSI has authority to issue guidelines to insurance companies with respect to corporate governance and internal controls. In this regard the OSI intends to issue standard operations guidelines using the IAIS model and will enforce them where appropriate.

Also, the OSI has been in contact with CARTAC for technical assistance in training for OSI staff, especially in the areas of reinsurance and on-site inspection, which is now being scheduled. OSI will embark on an onsite inspection of insurance agents in the summer of 2004. In addition, examinations for intermediaries are contemplated and the administration/grading of the examination are being discussed by the industry and OSI. 


\section{FATF Recommendations--Anti-Money Laundering and Combating the Finance of Terrorism (AML/CFT)}

\section{Introduction}

116. This Report on the Observance of Standards and Codes for the FATF 40 Recommendations for Anti-Money Laundering and 8 Special Recommendations on Terrorist Financing of Terrorism was prepared by a team composed of staff of the International Monetary Fund experts under the supervision of Fund staff, and another expert not under the supervision of Fund and Bank staff who was selected from a roster of experts in the assessment of criminal law enforcement and non-prudentially regulated financial activities. ${ }^{3}$

117. The report provides a summary of the level of observance with the FATF $40+8$ Recommendations, and provides recommendations to strengthen observance. The assessment is based on the 2002 Methodology for Assessing Compliance with Anti-Money Laundering and Combating the Financing of Terrorism (Final Version, October 2002). The views expressed in this document are those of the assessment team and do not necessarily reflect the views of the government of Belize or the Board of the IMF.

\section{Information and methodology used for the assessment}

118. In preparing the detailed assessment, Fund staff and another expert under the supervision of Fund staff reviewed the relevant AML/CFT laws and regulations, and supervisory and regulatory systems in place to deter money laundering and financing of terrorism among prudentially regulated financial institutions. The framework for Offshore Mutual Funds and International Financial Services was reviewed but the domestic securities sector was not reviewed as it was not macro-relevant. In addition, the Fund staff and another expert under their supervision reviewed the regulatory systems in place for non-prudentially regulated sectors that are macro-relevant, specifically trust and company service providers, credit unions and casa de cambios. Another expert not under the supervision of Fund staff reviewed the capacity and implementation of criminal law enforcement systems. The assessment is based on the information available at the time it was completed on August 14, 2003.

\footnotetext{
${ }^{3}$ The team consisted of John Abbott (Mission Chief, IMF/MFD), Joseph Courtright (MFD banking supervision consultant, formerly with OSFI, Canada); Peter Kruschel (BCPs, BaFin, Germany); Martin Roberts (MFD, insurance consultant, formerly with FSAS, U.K.); Ms. Joy K. Smallwood (IMF/LEG); Russell Ursula ((responsible for the criminal justice elements of the methodology, CFATF); and Richard Walker (responsible for the supervisory/preventive measures sections of the methodology, Guernsey Financial Services Commission). The roster of experts for the IAE is based on the names of competent persons identified by the FATF, FSRBs, the United Nations, and the Egmont Group.
} 


\section{Main findings}

119. Belize has made significant progress towards establishing an AML/CFT legislative framework. In 2002 Belize enacted the FIU Act, amended the Money Laundering Prevention Act and amended the International Banking Act thereby strengthening the AML/CFT regime. Belize is now embarking on the second phase of its initiatives, namely the implementation phase. To respond to requests from overseas regulatory and investigative agencies, the FIU has taken responsibility for collecting information from domestic financial institutions and sharing that information with overseas authorities. It also intends to issue updated guidance notes. The Central Bank of Belize has, for some time, been undertaking AML onsite inspections. The acting Superintendent of Insurance ("SOI") has commenced a series of onsite visits utilizing the insurance specific criteria from the Bank/Fund Methodology.

120. While the enactment of the MLPA and the MLPR have significantly enhanced the AML/CFT framework, provisions regarding freezing of proceeds of predicate offences are not available and weaken the overall structure. While the FIU has the authority to respond to inquiries from relevant authorities, there is no mutual assistance legislation which would provide an additional gateway for assistance. Similarly, there are limited provisions for regulatory authorities to share information in respect of regulatory or criminal enquiries.

121. A significant challenge facing the authorities is the establishment of an overall mechanism for effective implementation of the AML/CFT framework. The FIU is vested with broad powers of investigation and prosecution. In addition, the FIU is the Supervisory Authority for the purposes of the MLPA and MLPR and is responsible for issuing AML/CFT guidance and training requirements to financial institutions. The MLPR and the Notes are in need of updating. This will be a challenging task given that the FIU proposes to make the MLPR and guidance relevant to all FIs. The guidance notes need to be strengthened in the areas of: the issuance of guidance to the insurance sector; the inclusion of standards on CFT; the verification of the true identity of customers and beneficial owners; appropriate standards for introduced business; what records should be kept, the time for which they are kept and their location; which staff of financial institutions should be trained and the level of training to be provided; adequate screening procedures to ensure high standards when hiring employees; strengthening the procedures for the recognition and reporting of suspicious transactions; and group practice.

122. The Central Bank of Belize and the two insurance supervisory bodies have separate responsibilities under international supervisory standards to issue sector specific AML guidance. The IFSC will be required to update the IFSCR. Careful consideration will need to be given to ensuring that all relevant regulatory bodies can meet their international responsibilities.

123. The FIU also has responsibility to "ensure coordination and cooperation between law enforcement agencies, government departments, regulatory authorities, private institutions 
and members of relevant professions in evolving methods and policies to prevent and suppress financial crimes." The FIU also has the authority to conduct prosecutions of ML and FT cases. Given the large number of both regulatory bodies and law enforcement authorities, significant time and resources will be required to construct an effective framework with clear lines of responsibility and where all parties cooperate fully. This will be a significant undertaking as the FIU is a new body and, historically, few resources have been dedicated to countering economic crime. Significant training will be required in all sectors.

124. This regulatory framework exists against a backdrop of financial products which are particularly susceptible to abuse by money launderers, including asset protection trusts, international mutual funds, and IBCs where the business purpose and the ultimate beneficial owner may not be known to the local Belizean administrator. Strengthened customer due diligence requirements, on-site monitoring and training of staff in local financial institutions are required to combat potential abuse.

\section{Criminal justice measures and international cooperation}

\section{Criminalization of ML and FT}

125. Money laundering is criminalized as an indictable offence, extends to all proceeds of criminal conduct for crimes that are listed offences and is consistent with the definitions set out in the Vienna Convention, and the FATF 40 Recommendations. The list of offences which are predicate offences should be broadened. FT is not criminalized although terrorism is criminalized. FT should be criminalized. With respect to criminal offences, both individuals and corporate entities are subject to criminal laws relating to money laundering. Belize should ratify the UN Convention against Transnational Organized Crime (Palermo Convention) as well as the 1999 International Convention on the Suppression of Financing of Terrorism.

\section{Confiscation of proceeds of crime or property used to finance terrorism}

126. The MLPA allows for freezing and seizure of the proceeds of a ML conviction but does not allow for the confiscation of proceeds of crime from predicate offences or FT. In order to confiscate proceeds from a predicate offence, sections 106 and 107 of the Summary Jurisdiction Procedure Act must be used as they provide for the confiscation of funds or property that are the proceeds of crime or property that has been converted from the proceeds of crime, after conviction. Similarly, there are identical provisions which exist in Sections 182-186 of the Indictable Offences Act. These provisions could not be used for FT as FT is not criminalized. Therefore, freezing of terrorist funds is possible but confiscation of funds used to finance terrorism is not possible. Freezing funds from predicate offences is also not possible and provisions should be enacted in order to strengthen the AML/CFT framework in this regard. More active enforcement of the confiscation provisions would also be welcome. 
127. There has been some level of training and awareness on ML/FT issues for a limited section of law enforcement officials in Belize. However, ongoing training and awareness for enforcing laws related to the freezing, seizure and confiscation of property to wider groups of administrative, investigative, prosecutorial, and judicial authorities in Belize has not been an ongoing feature. There is a pressing need for seminars on the use and enforcement of the, relatively new, ML/FT legislation in large sections of the administrative and law enforcement agencies of Belize. This should also include training in convictions and more use of seizure and confiscation of assets provisions which is also needed for the DPP's office, Judges and magistrates. Customs, Defense Force and Immigration also needs to be sensitized more on the issue of ML/FT and cross border movements of cash and other monetary instruments.

\section{The FIU and the process for receiving, analyzing, and disseminating intelligence}

128. The FIU in Belize was established in September 2002 and became operational in December 2002 significantly strengthening the AML/CFT framework. The FIU is mandated to receive suspicious transaction reports but not to analyze them. Further, the Director of the FIU may request information from any financial institution in furtherance of an investigation being carried out either in Belize or elsewhere. Section 12(2) of the FIUA allows the Director of the FIU to impart information obtained under the MLPA or the FIUA to: "an agency in Belize or abroad, such information, as may appear to him to be necessary to assist an investigation or prosecution of a money laundering or other financial crime." While this is a welcome addition to the AML/CFT framework, it should not be used indefinitely as a way to work around the lack of other gateways in the AML/CFT framework. The broad scope of the authority of the FIU has led to confusion in the regulatory and the financial communities. Clear policy decisions on the role of the FIU are recommended. The Director has undertaken a number of inquiries at the request of foreign agencies.

129. The FIU maintains statistics of received, analyzed and disseminated STR's and is now in the process of acquiring a software program to store the data electronically. STR's up to now have not resulted in prosecution and conviction. Before the inception of the FIU STR's were received by the Central Bank as the former supervisory authority and sent to Belize Defense Force for investigations. The BPD and the FIU have well kept statistics on received and investigated STR's prior to the establishment of the FIU (November 2002). The FIU also maintains well-kept statistics on all domestic and foreign requests for assistance in the investigation of financial crimes. The basic structure seems adequate. However, taking into account the vast responsibilities of the FIU, more than the current four professional staff will be required.

\section{Law enforcement and prosecution authorities, powers, and duties}

130. The current legal framework offers sufficient scope for law enforcement agencies to ensure that ML and FT offences are properly investigated and prosecuted although in practice these matters are now within the jurisdiction of the FIU and this has caused some confusion between the authorities as to which agency has jurisdiction over which matters. When law enforcement is investigating predicate offence crimes, they have the authority 
under the Criminal Code to execute warrants but in practice, when requiring records from FIs, law enforcement relies on the FIU to obtain such information from the FIs. Further, the government should consider the most effective method for coordinating the investigation and prosecution predicate offences along with ML/FT offences. Current plans include having the FIU investigate and prosecute ML (and later FT) matters and having the DPP separately prosecute the underlying predicate offence. This would lead to confusion, inefficiency and overlapping of jurisdiction. There is room for more cooperation and information exchange on a permanent basis between existing law enforcement entities. The FIU is the entity to coordinate the work of the different law enforcement entities in the area of AML/CFT efforts. The FIU should develop itself more in the future in order to step up this coordination task.

131. There is no specific mutual legal assistance act. This would be a useful addition to the legislative framework and would provide a clear methodology for rendering assistance. Currently, it is unclear whether mutual assistance can be rendered generally as there is a provision in the MLPA concerning ML matters only. Further detailed provisions should be implemented. A 2002 amendment to the MLPA has removed the need for a treaty in order for mutual legal assistance to be rendered so that the law is now silent on that matter. While Belize is not a party to any multilateral mutual assistance treaties, Belize has executed a bilateral MLAT with the United States There is an Extradition Act as well as a number of Extradition Treaties signed by the United Kingdom on behalf of Belize before independence. Belize continues to be a party to those treaties on a successor basis.

132. The authorities have made a good start in establishing an AML framework with regard to the standards to be followed by financial institutions. The standards which the authorities have implemented are encapsulated in the Money Laundering Prevention Act, the Money Laundering Prevention Regulations, the IFSC (Code of Conduct) Regulations and the Money Laundering (Prevention) Guidance Notes. The Central Bank of Belize and the Office of the Supervisor of Insurance conduct onsite visits to supervised institutions. The framework now needs to be strengthened with the introduction of enhanced standards on customer identification, the ongoing monitoring of accounts and transactions, record keeping, suspicious transaction reporting and internal controls, compliance and audit. In addition, the IFS Commissioner should commence onsite visits to international financial services practitioners.

\section{Summary assessment against the FATF Recommendations}

133. Belize has made significant progress towards compliance with many of the FATF Recommendations and the Special Eight Recommendations on Terrorist Financing. Recent additions to the AML/CFT framework include the establishment of the FIU and the amendment of the Money Laundering Prevention Act to include freezing provisions and provisions which criminalize both terrorism and the financing of terrorism. Belize has also ratified the UN Convention for the Suppression of the Financing of Terrorism.

134. The following provisions would further enhance the AML/CFT framework: introducing legislation to allow for the freezing of assets from economic crime and predicate 
offences, the exchange of information through regulatory gateways, the identification of customers of financial instructions by an official document, and the filing of a STR for suspicious transactions involving FT. Ratifying the Palermo Convention and enacting a mutual legal assistance act would further strengthen the AML/CFT regime. The FIU has been established with broad powers but careful consideration needs to be given to the mechanisms for the effective performance of its role. The FIU will be required to ensure co-ordination and cooperation between law enforcement agencies, government departments, regulatory authorities, private institutions and members of relevant professions in policies to prevent and suppress financial crimes. The developing system of AML/CFT and financial regulation will require additional resources and training.

Table 5. Recommended Action Plan to Improve Compliance with the FATF Recommendations

\begin{tabular}{|c|c|}
\hline Reference FATF Recommendation & Recommended Action \\
\hline 40 Recommendations for AML & \\
\hline $\begin{array}{l}\text { General framework of the Recommendations } \\
\text { (FATF 1-3) }\end{array}$ & $\begin{array}{l}\text { Sign and ratify the Palermo Convention. } \\
\text { Ratify the } 1999 \text { International Convention on the Suppression of } \\
\text { Financing of Terrorism. } \\
\text { Amend the definition of ML to include omissions as well as } \\
\text { "acquires, converts or uses" property that is the proceeds of } \\
\text { crime. } \\
\text { Criminalize FT. } \\
\text { Expand the list of predicate offences or take an all crimes } \\
\text { approach to predicate offences as indicated to the mission. } \\
\text { Expand the range of sanctions across the regulatory legislation } \\
\text { to include: issuance of a written directive or order, issuance of a } \\
\text { public statements, placing conditions on a license, suspension or } \\
\text { removal of directors and officers, objections to controllers, } \\
\text { removal and disqualification of an external auditor, appointment } \\
\text { of a special auditor at the expense of a licensee, appointment for } \\
\text { a defined period of a provisional or temporary administrator } \\
\text { (typically with court approval), imposition of a range of } \\
\text { administrative fines on licensees, directors and senior managers, } \\
\text { and revocation of a license. }\end{array}$ \\
\hline
\end{tabular}




\begin{tabular}{|c|c|}
\hline Provisional measures and confiscation (FATF 7) & $\begin{array}{l}\text { Amend the relevant legislation to allow for freezing of proceeds } \\
\text { of crime generally rather than merely proceeds from a ML or } \\
\text { FT offence. } \\
\text { Consider amending the MLPA to allow for the inference that } \\
\text { assets acquired before the commission of the offense are } \\
\text { proceeds of crime where there is no other economic explanation } \\
\text { for the assets having been acquired, tracking a provision already } \\
\text { in place in the MDA. } \\
\text { Amend Section } 7 \text { of the MLPA to include provisions making it } \\
\text { an offence for a person to disclose the existence of monitoring } \\
\text { orders or production orders. } \\
\text { Consider provisions to void contracts or render them } \\
\text { unenforceable where parties to the contract knew or ought to } \\
\text { have known that as a result to the contract the authorities would } \\
\text { be prejudiced in their ability to recover financial claims } \\
\text { resulting from the operation of AML/CFT laws. } \\
\text { Consider creating an asset forfeiture fund in which all or a large } \\
\text { portion of the confiscated property will be deposited and will be } \\
\text { used for law enforcement, health or education purposes. } \\
\text { Consider asset sharing with other countries regarding ML/FT } \\
\text { seizures. }\end{array}$ \\
\hline $\begin{array}{l}\text { General role of financial system in combating ML } \\
\text { (FATF 8-9) }\end{array}$ & See comments for FATF Recommendations 10-29 \\
\hline $\begin{array}{l}\text { Customer identification and record-keeping rules } \\
\text { (FATF 10-13) }\end{array}$ & $\begin{array}{l}\text { Amend the MLPA and the Notes to expressly prohibit } \\
\text { FIs from keeping anonymous accounts or accounts in } \\
\text { fictitious names. } \\
\text { Amend the MLPA, MLPR and the IFSCR to require all } \\
\text { customers to be identified on the basis of an official } \\
\text { document. Access to identification documentation } \\
\text { should be available immediately. } \\
\text { Strengthen requirements in the MLPR regarding the } \\
\text { verification of identity of corporations. } \\
\text { Include a provision in the MLPR and the Notes } \\
\text { regarding numbered accounts. } \\
\text { Amend the MLPR and the Notes to require that FIs } \\
\text { verify the true identity of customers. } \\
\text { Amend the MLPR and IFSCR to require that relevant records be } \\
\text { maintained in Belize so that regulated entities must know the } \\
\text { beneficial ownership of their client before they conduct the } \\
\text { transaction. }\end{array}$ \\
\hline
\end{tabular}




\begin{tabular}{|c|c|}
\hline & $\begin{array}{l}\text { Amend the MLPR, the IFSCR and the Notes to state that } \\
\text { account files and business correspondence should be maintained } \\
\text { for at least five years following the termination of an account or } \\
\text { business relationship. } \\
\text { Amend the MLPA and the Notes to state that records } \\
\text { maintained within the statutory timeframe should be available in } \\
\text { Belize for inspection by a competent authority. }\end{array}$ \\
\hline $\begin{array}{l}\text { Increased diligence of financial institutions (FATF } \\
14-19 \text { ) }\end{array}$ & $\begin{array}{l}\text { Amend the MLPR and the Notes to provide details requiring FIs } \\
\text { to pay special attention to all complex, unusual large } \\
\text { transactions, or unusual patterns of transactions, that have no } \\
\text { apparent or visible economic or lawful purpose, to examine as } \\
\text { far as possible the background and purpose of such transactions, } \\
\text { and to set forth their findings in writing. } \\
\text { Amend the MLPA to include the requirement to file a STR for } \\
\text { suspicious transactions involving FT. } \\
\text { Amend the MLPA and the MLPR to require STRs to be made in } \\
\text { writing. } \\
\text { Amend the MLPA to establish a test of "ought reasonably to } \\
\text { have known" as the test liability for failure to file STRs which is } \\
\text { the international practice rather than the current test of } \\
\text { willfulness. } \\
\text { The Notes should be amended to provide detail requiring FIs to } \\
\text { pay special attention to all complex, unusual large transactions, } \\
\text { or unusual patterns of transactions, that have no apparent or } \\
\text { visible economic or lawful purpose, to examine as far as } \\
\text { possible the background and purpose of such transactions, and } \\
\text { to set forth their findings in writing, }\end{array}$ \\
\hline $\begin{array}{l}\text { Measures to cope with countries with insufficient } \\
\text { AML measures (FATF 20-21) }\end{array}$ & $\begin{array}{l}\text { Amend the MLPR, the IFSCR and the Notes to require FIs to } \\
\text { ensure that their foreign branches and subsidiaries observe } \\
\text { appropriate AML/CFT measures consistent with home } \\
\text { jurisdiction requirements, to the extent that local laws and } \\
\text { regulations permit and require FIs to inform their home } \\
\text { jurisdiction supervisor/regulator when a foreign branch or } \\
\text { subsidiary is unable to observe the appropriate AML/CFT } \\
\text { measures of the home jurisdiction. } \\
\text { Amend the MLPA to require financial institutions to pay } \\
\text { particular attention to business relations and transactions with } \\
\text { persons in jurisdictions that do not have adequate systems to } \\
\text { prevent ML or FT. }\end{array}$ \\
\hline
\end{tabular}




\begin{tabular}{|c|c|}
\hline & $\begin{array}{l}\text { Amend the MLPR and the Notes to require FIs to give special } \\
\text { attention to business relations and transactions with persons } \\
\text { (including legal entities and other financial institutions) in } \\
\text { jurisdictions that do not have adequate systems in place to } \\
\text { detect ML or FT. If those transactions have no apparent } \\
\text { economic or visible lawful purpose, the background and } \\
\text { purpose of such transactions should, as far as possible, be } \\
\text { examined, and written findings should be available to assist } \\
\text { competent authorities such as supervisors, law enforcement } \\
\text { agencies and the FIU and auditors. }\end{array}$ \\
\hline $\begin{array}{l}\text { Implementation and role of regulatory and other } \\
\text { administrative authorities (FATF 26-29) }\end{array}$ & $\begin{array}{l}\text { Amend the MLPA to require STRs to be filed for suspicious } \\
\text { transactions relating to FT. } \\
\text { The FIU should issue guidelines on the identification of } \\
\text { complex or unusual transactions. } \\
\text { Widen the fit and proper test for a criminal record to include all } \\
\text { significant crimes and not merely crimes of dishonesty and } \\
\text { apply this test to controllers, directors and managers across all } \\
\text { financial institutions so that they can be removed or prevented } \\
\text { from taking office. } \\
\text { Conduct onsite inspections across the entire regulated industry. }\end{array}$ \\
\hline $\begin{array}{l}\text { Administrative Cooperation - Exchange of } \\
\text { information relating to suspicious transactions } \\
\text { (FATF 32) }\end{array}$ & $\begin{array}{l}\text { Amend each piece of legislation dealing with regulatory } \\
\text { powers, to include the permitting of cooperation, spontaneously } \\
\text { or upon request, with other Belizean competent authorities } \\
\text { including the lending of expertise with respect to AML/CFT } \\
\text { analysis, investigations and prosecutions. }\end{array}$ \\
\hline $\begin{array}{l}\text { Other forms of cooperation - Basis and means of } \\
\text { cooperation in confiscation, mutual assistance, and } \\
\text { extradition (FATF 33-35) }\end{array}$ & $\begin{array}{l}\text { Enact a law which specifically provides for the widest possible } \\
\text { range of mutual assistance with regard to AML/CFT matters } \\
\text { and predicate offences and includes details regarding exact } \\
\text { procedures for obtaining mutual assistance including the level } \\
\text { of detail required to be produced in order to obtain assistance } \\
\text { and the exact form of a request. } \\
\text { Law enforcement authorities should have the ability to share } \\
\text { information with their law enforcement counterparts apart from } \\
\text { Interpol. }\end{array}$ \\
\hline $\begin{array}{l}\text { Other forms of cooperation - Focus of improved } \\
\text { mutual assistance on money laundering issues } \\
\text { (FATF 36-40) }\end{array}$ & $\begin{array}{l}\text { Enact a law which specifically provides for the widest possible } \\
\text { range on mutual assistance with regard to AML/CFT matters } \\
\text { and predicate offences and includes details regarding exact } \\
\text { procedures for obtaining mutual assistance including the level } \\
\text { of detail required to be produced in order to obtain assistance } \\
\text { and the exact form of a request. }\end{array}$ \\
\hline $\begin{array}{l}8 \text { Special recommendations on terrorist } \\
\text { financing }\end{array}$ & \\
\hline
\end{tabular}




\begin{tabular}{|c|c|}
\hline $\begin{array}{l}\text { I. Ratification and implementation of UN } \\
\text { Instruments }\end{array}$ & $\begin{array}{l}\text { Ratify the } 1999 \text { International Convention on the Suppression of } \\
\text { Financing of Terrorism. } \\
\text { Criminalize FT. }\end{array}$ \\
\hline $\begin{array}{l}\text { II. Criminalizing the financing of terrorism and } \\
\text { associated money laundering }\end{array}$ & $\begin{array}{l}\text { Criminalize FT and ensure that FT is a predicate offence for } \\
\text { ML. }\end{array}$ \\
\hline III. Freezing and confiscating terrorist assets & $\begin{array}{l}\text { Criminalize FT and ensure that FT is a predicate offence for } \\
\text { ML. }\end{array}$ \\
\hline $\begin{array}{l}\text { IV. Reporting suspicious transactions related to } \\
\text { terrorism }\end{array}$ & $\begin{array}{l}\text { Amend the MLPA to include the requirement to file a STR for } \\
\text { suspicious transactions involving FT. } \\
\text { Amend the MLPA and the MLPR to require STRs to be made in } \\
\text { writing. } \\
\text { Establish a test of "ought reasonably to have known" as the test } \\
\text { liability for failure to file STRs which is the international } \\
\text { practice rather than the current test of willfulness. }\end{array}$ \\
\hline V. International Cooperation & $\begin{array}{l}\text { Enact a law which specifically provides for the widest possible } \\
\text { range of mutual assistance with regard to AML/CFT matters } \\
\text { and predicate offences. }\end{array}$ \\
\hline VI. Alternative remittance & $\begin{array}{l}\text { Ensure that all service providers for the transmission of money } \\
\text { or value, including transmission through an informal money or } \\
\text { value transfer system, are licensed and subject to all the FATF } \\
\text { Recommendations that apply to banks and non-bank financial } \\
\text { institutions. Persons or legal entities that carry out this service } \\
\text { illegally should be subject to administrative, civil and criminal } \\
\text { sanctions. }\end{array}$ \\
\hline VII. Wire transfers & $\begin{array}{l}\text { Amend the MLPR, the IFSCR and the Notes within the } 2 \text { year } \\
\text { timeframe permitted by the FATF to state that the transaction } \\
\text { records to be maintained for wire transfers should include the } \\
\text { customer's (and beneficiary's) name, address (or other } \\
\text { identifying information normally recorded by the intermediary), } \\
\text { the nature and date of the transaction, the type and amount of } \\
\text { currency involved, and the type and identifying number of any } \\
\text { account involved in the transaction. }\end{array}$ \\
\hline
\end{tabular}


Table 6. Other Recommended Actions

\begin{tabular}{|l|l|}
\hline Reference & \multicolumn{1}{|c|}{ Recommended Action } \\
\hline FIU & $\begin{array}{l}\text { The central function of the FIU, to analyze STRs, is now } \\
\text { implicit in the FIU's operational activities but is not explicitly } \\
\text { mandated in its authorizing legislation. When amending } \\
\text { relevant legislation, introduce specific language mandating the } \\
\text { FIU to analyze, as well as to receive, STRs. } \\
\text { Consider whether the police commissioner having the power to } \\
\text { appoint police officers to the FIU conflicts with the } \\
\text { independence of the FIU. } \\
\text { Subject Auditors and Regulatory Authorities to the } \\
\text { requirements for filing STRs when they discover a suspicious } \\
\text { transaction in the course of their inspections of financial } \\
\text { institutions. } \\
\text { Amend the MLPA to require STRs to be filed for suspicious } \\
\text { transactions relating to FT. } \\
\text { Issue guidelines regarding the identification of complex or } \\
\text { unusual transactions. }\end{array}$ \\
\hline
\end{tabular}

\section{Authorities' response}

The Belize government is strongly committed to implementing a robust regime for antimoney laundering, as evidenced by recent developments, most notable the establishment of the Financial Intelligence Unit in 2002 with substantial responsibility for overseeing the AML regime. The authorities appreciate the comprehensive assessment that has been conducted by the International Monetary Fund. The report provides a fair evaluation of the strengths and weakness of the Belize AML/CFT regime, with numerous concrete recommendations for further strengthening the system. We concur with almost all of the recommendations in the suggested action plan and will be taking appropriate steps to implement them.

Since the assessment mission, further extensive training has been provided to the financial sector, including training provided by the Fund for financial supervisors in the techniques for insuring that financial institutions comply with their obligations under the AML regulations. Additional, later this year the IMF will be organizing specialized training for insurance supervisors, and we are grateful for that assistance. Many of the recommendations in the report will require amendments to legislation, or new laws. To help us further improve our AML/CFT framework, we have recently asked the IMF for technical assistance in drafting legislative amendments in accordance with the revised FATF 40+8 Recommendations, as well as other relevant conventions and UN Resolution. We are pleased that the Fund has also indicated its willingness to support us in this work. 
With respect to a few points we believe the objective of some recommendations may be satisfied administratively, without the need for revised legislation. For example, current legislation gives adequate scope for a strong analytical function within the FIU and it is our intention to take advantage of this existing authority. Also, we believe that arrangements for staffing of the FIU through police secondments can be best handled through bilateral discussions between the FIU and the Commissioner of Police rather than the more formal structure recommended by the IMF assessors. In any case, we look forward to working cooperatively with the IMF as we continued to strengthen our AML/CFT regime. 